Geohydrology of Hualapai

and Sacramento Valleys,

Mohave County, Arizona

GEOLOGICAL SURVEY WATER-SUPPLY PAPER 1899-H Prepared in cooperation with the
Arizona State Land Department Prepared in cooperation with the
Arizona State Land Department

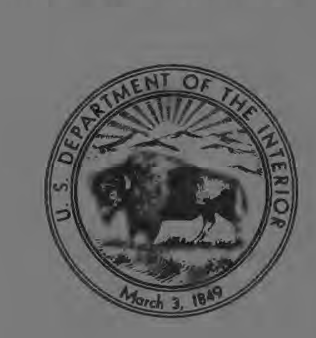




\section{LIRRARY COPY
U. S. GLO.OOICAL SURVEY, WRD
ROULA, WISSOUR \\ ROLLA, MISSOURL \\ LIRRARY COPY
U. S. GLO.OOICAL SURVEY, WRD
ROULA, WISSOUR \\ ROLLA, alssount \\ .}

(1)

1

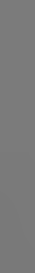

.

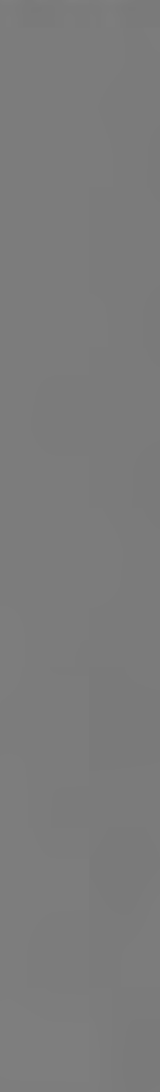




\section{Geohydrology of Hualapai}

and Sacramento Valleys, Mohave County, Arizona By J. B. GILLESPIE and C. B. BENTLEY

CONTRIBUTIONS TO THE HYDROLOGY OF THE UNITED STATES

GEOLOGICAL SURVEY WATER-SUPPLY PAPER 1899-H

Prepared in cooperation with the Arizona State Land Department

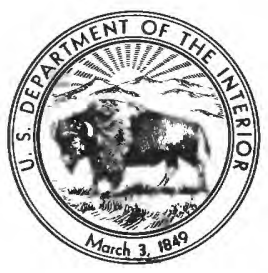

U. S. G. S.
WATER RESOURCES DIVISION
R E C E I V V E D
JAN 241972
AM M
$7,8,9,10,11,121,2,3,4,5,6$




\section{UNITED STATES DEPARTMENT OF THE INTERIOR}

ROGERS G. B. MORTON, Secretary

\section{GEOLOGICAL SURVEY}

W. A. Radlinski, Acting Director

Library of Congress catalog-card No. 72-609947 


\section{CONTENTS}

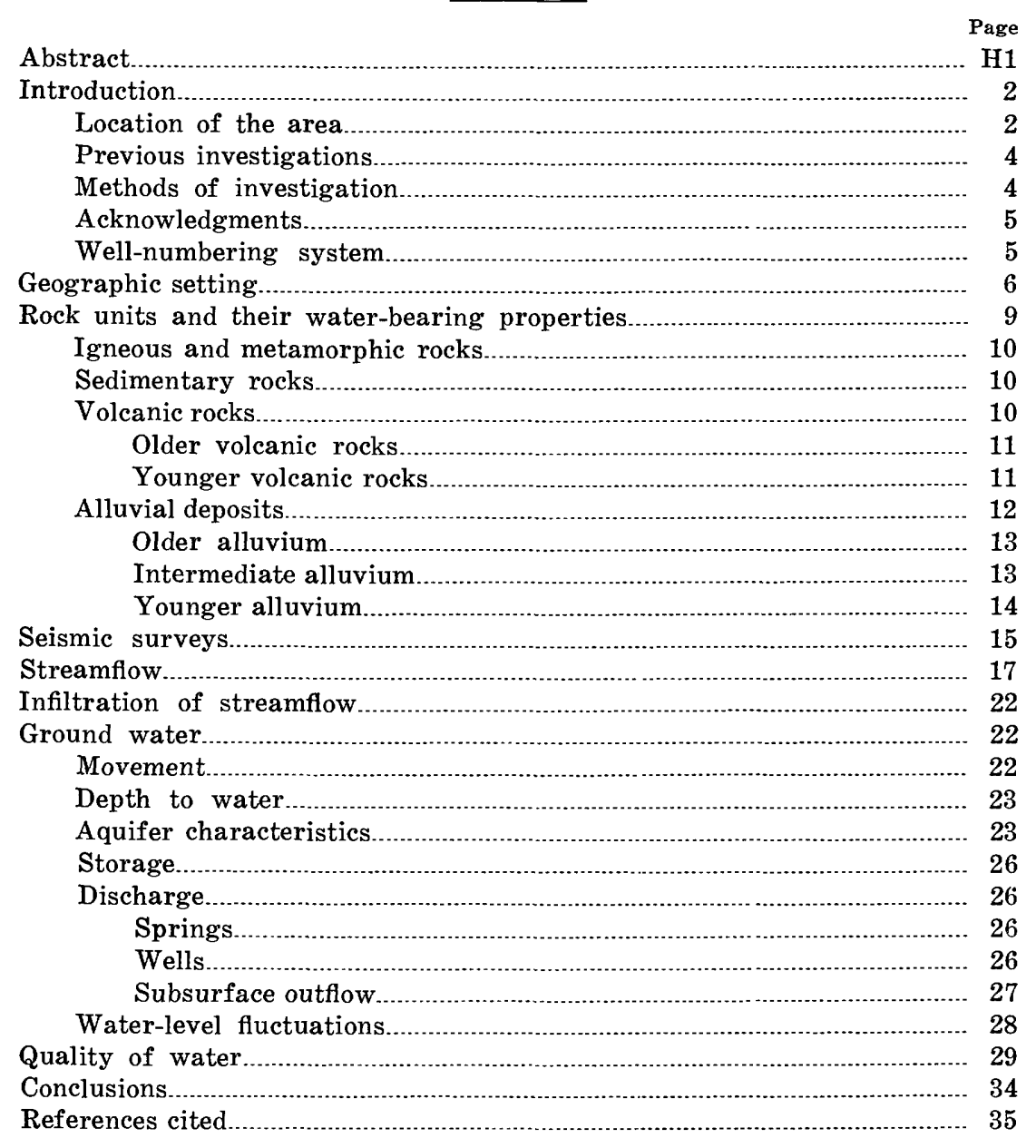

\section{ILLUSTRATIONS}

Plate 1. Geohydrologic map of the Hualapai and Sacramento Valleys, Mohave County, Arizona. In pocket

2. Seismic profiles and their analyses, Hualapai and Sacramento Valleys. 
Figure 1. Map showing physiography of northwestern

Arizona and area of report.

H3

2. Sketch showing well-numbering system in Arizona

3. Map showing the effect of orography on average annual precipitation in northwestern Arizona

4. Hydrographs showing flood stage at Truxton Wash at Valentine gaging station.

5. Hydrographs showing water levels in selected wells in Hualapai Valley.

6. Hydrographs showing water levels in selected wells in Sacramento Valley.

\section{TABLES}

TABLE 1. Peak discharges at gaging stations on streams in

Hualapai and Sacramento Valleys and adjacent areas. H19

2. Hydrologic characteristics determined from well data, Hualapai and Sacramento Valleys.

3. Estimated subsurface outflow from Hualapai and

Sacramento Valleys.

4. Chemical analyses of water in Hualapai and

Sacramento Valleys. 


\title{
CONTRIBUTIONS TO THE HYDROLOGY \\ OF THE UNITED STATES
}

\section{GEOHYDROLOGY OF HUALAPAI AND SACRAMENTO VALLEYS, MOHAVE COUNTY, ARIZONA}

\author{
By J. B. Gillespie and C. B. Bentley
}

\begin{abstract}
Ground water is the main water supply in the semiarid Hualapai and Sacramento Valleys, which are in Mohave County in northwestern Arizona. The valleys are intermontane basins, which are filled to depths of more than 4,000 feet with alluvial deposits and volcanic rocks. The adjacent mountain ranges are tilted fault blocks and consist of igneous and metamorphic rocks that are mainly Precambrian in age, sedimentary rocks of Paleozoic age, and volcanic rocks, which are divided into the older volcanic rocks of Mesozoic(?) and Cenozoic age and the younger volcanic rocks of Tertiary age. The alluvial deposits in Hualapai and Sacramento Valleys are divided into the older alluvium of Tertiary age, the intermediate alluvium of Tertiary and Quaternary age, and the younger alluvium of Quaternary age. The older alluvium and the younger volcanic rocks are the most important aquifers in the area.

The streams in Hualapai and Sacramento Valleys are ephemeral, although a few intermittent streams are present in the mountains. Substantial streamflow occurs in the mountains as a result of high-intensity storms, but the flows seldom reach the middle of the valleys; most of the flow is lost to infiltration and evapotranspiration. About 9,000 acre-feet of streamflow infiltrates to the ground-water reservoir annually near the mountains, and about 6,000 acre-feet per year of streamflow reaches the valley floors, of which only about 500 acre-feet flows out of the study area as surface flow.

Ground water occurs in the older alluvium at depths ranging from about 70 to 150 feet in the Hackberry area and from 260 feet in the main part of Hualapai Valley to about 900 feet at the south end of the valley. The general movement of ground water in Hualapai Valley is northward, toward the Colorado River. In the main part of Sacramento Valley, ground water occurs in the older alluvium at depths ranging from less than 300 feet south of Yucca to more than 1,000 feet at the north end of the valley. The ground water moves southward in Sacramento Valley, and, where it leaves the report area, turns to the west and flows toward the Colorado River. Ground water occurs in the younger volcanic rocks at Kingman at depths ranging from about 100 to 125 feet. The estimated volume of ground water in storage to a maximum depth of 1,500 feet below land surface is 10.5-21 million acre-feet in Hualapai Valley and 6.5-13 million acre-feet in Sacramento Valley. About 3,600 acre-feet of water was pumped from wells in Hualapai Valley in 1967,
\end{abstract}


and about 4,200 acre-feet was pumped from wells in Sacramento Valley. Subsurface outflow is about 5,000 and 4,000 acre-feet per year from Hualapai and Sacramento Valleys, respectively. Water levels have remained almost constant in most of the area, but annual declines of as much as 7 feet have occurred in areas of large withdrawals. Ground water in the valleys is generally of good chemical quality, but in highly mineralized areas in and near the mountains, the ground water is unfit for human consumption.

\section{INTRODUCTION}

Hualapai and Sacramento Valleys (fig. 1) comprise an area of growing economic development, which is due mainly to the expansion of mining and industry near Kingman - the county seat of Mohave County. Because of the growing demand for an adequate and dependable water supply, an investigation of the water resources of Hualapai and Sacramento Valleys was undertaken as part of the program of water-resources investigations of the U.S. Geological Survey in cooperation with the Arizona State Land Department, Obed M. Lassen, Commissioner. The purpose of the study was to determine the availability and chemical quality of the water in the area. The study was under the immediate supervision of H. M. Babcock, district chief of the Water Resources Division in Arizona.

As used in this report, the term "main part of Sacramento Valley" includes all the valley except the Kingman well-field area. The term "main part of Hualapai Valley" includes all the valley except the Hackberry well-field area.

\section{LOCATION OF THE AREA}

Hualapai and Sacramento Valleys are in the central part of Mohave County in northwestern Arizona (fig. 1). Hualapai Valley is bounded on the east by the Grand Wash Cliffs, and on the west by the Cerbat Mountains. The valley trends northward and extends from the Hualapai Mountains on the south to a low topographic divide about 5 miles north of Red Lake. Sacramento Valley is bounded on the east by the Cerbat and Hualapai Mountains, and on the west by the Black Mountains. Sacramento Valley trends southward parallel to Hualapai Valley and extends from near Chloride on the north to the south end of the Black Mountains, near Yucca. The two areas comprise about 1,750 square miles. Kingman is in the low saddle between the Cerbat and Hualapai Mountains; the mountains form the divide between Hualapai Valley and Sacramento Valley. 


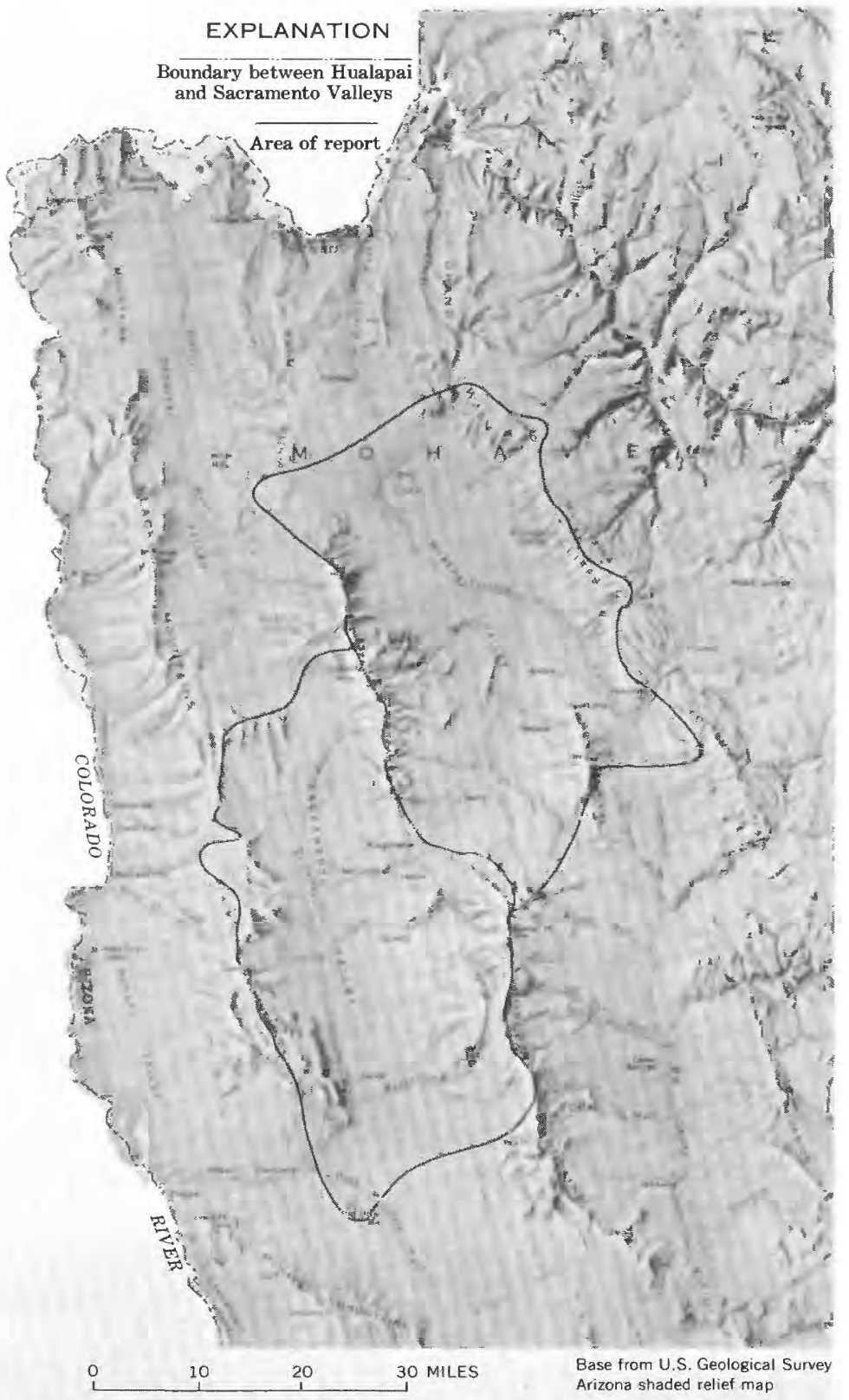

Figure 1. - Physiography of northwestern Arizona and area of report. 


\section{PREVIOUS INVESTIGATIONS}

Lee (1908), in a reconnaissance report on part of western Arizona, described the general geology of Hualapai and Sacramento Valleys and the surrounding areas, and Schrader (1909) investigated the geology and ore deposits. The economic geology of the Oatman gold district was discussed by Ransome (1923); Dings (1951) described the geology of the Wallapai mining district; and Wilson and Moore (1959) prepared a reconnaissance geologic map of Mohave County. Brief discussions of the water resources have been included in a few reports - Bowen and Turner (1943), Piper and Poland (1943), Turner (1943), Turner and Poland (1943), and Twenter (1962). The basic hydrologic data collected during this investigation were published in Arizona State Land Department Water-Resources Report 26 (Gillespie and others, 1966).

\section{METHODS OF INVESTIGATION}

The fieldwork for this investigation was started in July 1964 and was completed in April 1967. Continuous recording gages were installed on Truxton Wash at Valentine and Slaughterhouse Wash near Kingman for the collection of streamflow data. Ten crest-stage gages, eight of which were equipped with flood-hydrograph recorders, were installed to monitor runoff from the mountains onto the valley floors and to aid in calculating the amount of ground-water recharge that might occur along the stream channels. Because of the short period of record at these gaging stations, surface-water runoff onto the valley floors was estimated at 15 representative sites by using a method developed by Moore (1968).

Wells and springs in the area were inventoried. Well construction data were obtained from owners, well drillers, water companies, and the Arizona State Land Department. Spring discharge data were obtained from the U.S. Bureau of Land Management. Continuous water-level recording gages were installed on five wells, and depth to water was measured periodically in selected wells. Drillers' logs, lithologic logs, and drill cuttings were examined to determine subsurface lithology, and pumping tests were made to determine the hydraulic properties of the aquifer.

Water samples were collected from wells and from Red Lake for chemical analysis. Chemical analyses were also obtained from other agencies.

The geology was mapped on aerial photographs and transferred to a base prepared from maps compiled by the U.S. Army Map Service. The geology of the Grand Wash Cliffs area was modified from a report by Twenter (1962). Geologic mapping of the moun- 
tain areas was of the reconnaissance type, but the geology of the alluvial deposits was mapped in detail. Three seismic surveys were made in cooperation with the Branch of Astrogeology, U.S. Geological Survey. The data obtained from these surveys were used to estimate the thickness of the alluvium underlying the valley floors.

\section{ACKNOWLEDGMENTS}

The authors gratefully acknowledge the cooperation of the following individuals and firms, who furnished information relative to this study: Officials and employees of the city of Kingman and Mohave County; several water companies serving the area; personnel of the Duval Corp., Mineral Park mine; J. N. McDougal, County Agricultural Agent; T. E. Dingman, Bureau of Land Management; C. C. Sweetin, County Sanitarian; R. H. Godson, Branch of Astrogeology, U.S. Geological Survey; the well owners and operators; and the many well drillers in the area. R. E. Morrow, former State Senator from Mohave County, and W. W. Welsh, former Chairman, Mohave County Area Development Council, were especially helpful.

\section{WELL-NUMBERING SYSTEM}

The well numbers used by the U.S. Geological Survey in Arizona are in accordance with the Bureau of Land Management's system of land subdivision. The land survey in Arizona is based on the Gila and Salt River meridian and base line, which divide the State into four quadrants (fig. 2). These quadrants are designated, counterclockwise, by the capital letters A, B, C, and D. All land north and east of the point of origin is in A quadrant, that north and west in B quadrant, that south and west in C quadrant, and that south and east in $\mathrm{D}$ quadrant. The first digit of a well number indicates the township; the second, the range; and the third, the section in which the well is situated. The lowercase letters $a, b$, c, and $d$ after the section number indicate the well location within the section. The first letter denotes a particular 160 -acre tract; the second, the 40-acre tract; and the third, the 10 -acre tract. These letters also are assigned in a counterclockwise direction, beginning in the northeast quarter. If the location is known within the 10-acre tract, three lowercase letters are shown in the well number. In the example shown (fig. 2), well number (B-4-2) 19caa designates the well as being in the NE1/4 NE1/4.SW1/4. sec. 19, T. 4 N., R. $2 \mathrm{~W}$. Where there is more than one well within a 10-acre tract, consecutive numbers, beginning with 1 , are added as suffixes. 


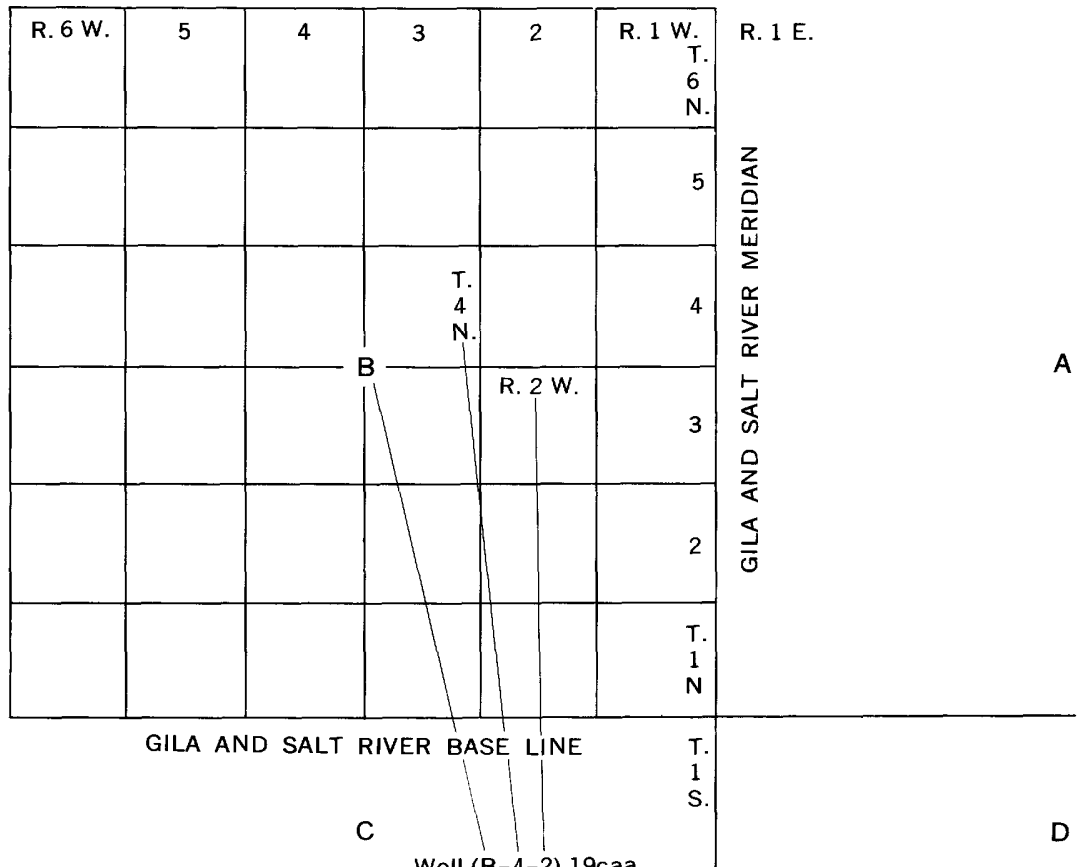

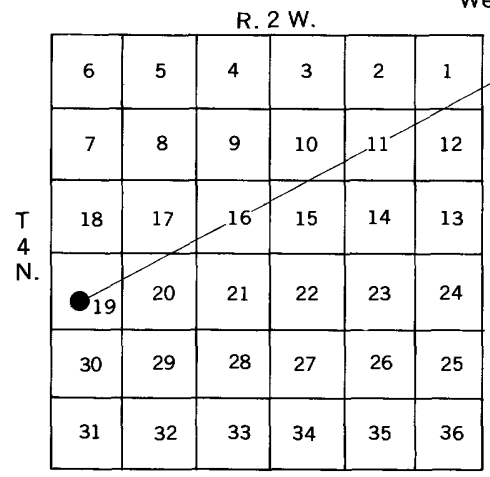

Sec. 19

Figure 2. - Well-numbering system in Arizona.

\section{GEOGRAPHIC SETTING}

Hualapai and Sacramento Valleys are intermontane basins that are filled with alluvial deposits and volcanic rocks to depths of more than 4,000 feet. The floor of Hualapai Valley slopes northward from an altitude of nearly 4,000 feet at the south end to 2,750 feet at Red Lake. The floor of Sacramento Valley slopes gently southward from nearly 3,500 feet at the north end to about 1,500 feet at the south end. The adjacent mountains rise abruptly 
above the valley floors; the peaks range in altitude from 5,000 feet in the Black Mountains to more than 8,000 feet in the Hualapai Mountains.

The Cerbat, Black, Hualapai, and Peacock Mountains are tilted fault blocks characteristic of the Basin and Range physiographic province, as described by Fenneman (1931). These mountains trend almost north. In the report area the Grand Wash Cliffs are the east boundary of the Basin and Range province, and the Colorado Plateaus province is to the east.

The climate of Hualapai and Sacramento Valleys is typically semiarid and is characterized by small amounts of precipitation and high summer temperatures, which - combined with the low humidity - cause high evaporation rates. In general, the annual precipitation increases with altitude (fig. 3), and at the higher altitudes in the Hualapai Mountains, the climate is subhumid. The upward movement of the air over the hot deserts and mountain barriers produces thunderstorms that yield locally intense precipitation, which results in rapid runoff from the mountains onto the valley floors (Green and Sellers, 1964, p. 237). The average annual precipitation ranges from about 6 inches at Red Lake to 20 inches or more on the higher peaks in the Hualapai Mountains (University of Arizona, 1965a, b).

The average annual precipitation at Kingman for the period 1912-66, as computed from records of the U.S. Weather Bureau, was 10.90 inches. The precipitation results from two types of storm patterns. The winter precipitation, which constitutes about 45 percent of the annual precipitation, is produced mostly by storms moving inland from the Pacific Ocean. The summer precipitation, which is greater than the combined total spring and fall precipitation, is associated mainly with the flow of warm moist air from the Gulf of Mexico.

At Kingman, temperature extremes have ranged from $6^{\circ} \mathrm{F}$ in January 1937 to $111^{\circ} \mathrm{F}$ in August 1933; the average annual temperature for the period 1902-57 was $61.4^{\circ} \mathrm{F}$ (Green and Sellers, 1964). Winter temperatures are usually in the upper fifties or lower sixties during the afternoon but are near freezing at night, and summer temperatures are usually in the upper nineties during the afternoon.

In general, streams in Hualapai and Sacramento Valleys are ephemeral; a few streams, such as Rock, Willow, and Walnut Creeks in the Hualapai Mountains, flow almost continuously in their upper reaches. Runoff from the mountains reaches the valley floors only in direct response to long-duration winter storms or to 


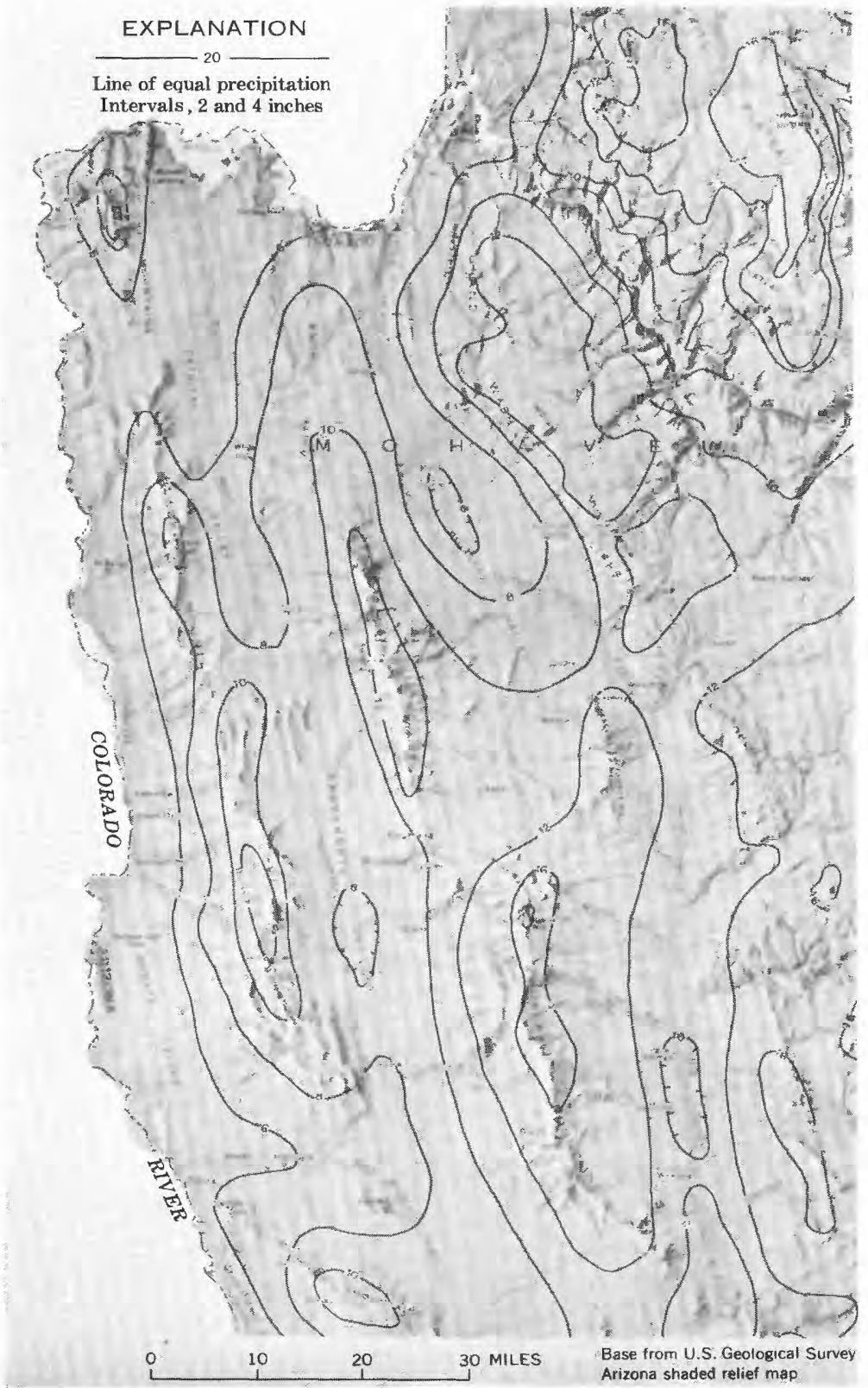

FigURE 3. - Effect of orography on average annual precipitation (1931-60) in northwestern Arizona. Precipitation data from University of Arizona $(1965 \mathrm{a}, \mathrm{b})$. 
high-intensity summer thunderstorms. Surface runoff seldom reaches the central part of the valleys. Most of the runoff infiltrates the coarse alluvium at the base of the mountains, and some eventually becomes recharge to the ground-water reservoir.

Vegetation at the lower altitudes is characterized by several varieties of cactus; yucca, including the Joshua-tree; and desert shrubs, such as mesquite, creosote bush, "palo Christi" (Canotia holacantha), and ocotillo. Grass is sparse on the valley floors and on the lower slopes of the mountains. The giant saguaro cactus, in what is probably its northernmost natural habitat, grows in sheltered canyons along the western foothills of the Hualapai Mountains. Juniper, pinyon pine, and scrub oak grow at intermediate altitudes, and ponderosa pine is abundant above an altitude of about 6,500 feet.

\section{ROCK UNITS AND THEIR WATER-BEARING PROPERTIES}

The consolidated rocks of the mountains of Hualapai and Sacramento Valleys consist of igneous and metamorphic, sedimentary, and volcanic rocks. The volcanic rocks are the most important aquifer in the mountain areas and are divided into older and younger volcanic rocks. The alluvial deposits which underlie the valley floors and occur along canyon bottoms in mountainous areas are divided into the older, intermediate, and younger alluvium. Further, the younger alluvium is divided into piedmont, stream, and playa deposits (pl. 1). The older alluvium is the aquifer that yields and stores the most water in the area.

Except for the intense folding in the highly contorted Precambrian metamorphic rocks, normal faulting has been the dominant structural process in rock deformation. Large intermontane faults bound individual ranges and plateaus, and small faults trend at different angles to the large faults and divide the mountain ranges into segments. Many minor faults and fractures are associated with the large and small faults.

Grand Wash fault, one of the major faults in northwestern Arizona, is on the east side of Haulapai Valley. It is a northwardtrending normal fault and is downthrown to the west. Displacement is about 4,000 to 6,000 feet along the fault at the Colorado River (Twenter, 1962, p. 23) ; about 1,000 feet of displacement has occurred since the emplacement of the younger volcanic rocks in the Grand Wash Cliffs and Peacock Mountains, near Hackberry. A similar fault may be present along the east side of Sacramento Valley, but, because of the great thickness of alluvium, it is not detectable. The Black and Cerbat Mountains appear to be faulted 
along their western flanks, and the strata dip $10^{\circ}-20^{\circ} \mathrm{E}$. Although several small faults were mapped, no attempt was made to map all the faults in the area. The valleys occupy the intervening troughs formed by the faulted and tilted mountain blocks.

\section{IGNEOUS AND METAMORPHIC ROCKS}

The oldest rocks exposed in the mountains consist of granite, gneiss, and schist of Precambrian age. The Precambrian rocks form the basement complex and are the lowermost barrier to the movement of ground water. Included with these rocks are small intrusive bodies of granitic composition. The intrusives are Late Cretaceous to early Tertiary in age and are associated with the "Laramide" copper-bearing rocks, which are being mined near Chloride. The igneous and metamorphic rocks generally do not yield water, except along fractures and in weathered zones; well yields from the weathered zones are generally from 1 to $5 \mathrm{gpm}$ (gallons per minute), although yields of as much as $30 \mathrm{gpm}$ have been reported. About 50 stock and domestic wells obtain water from the weathered zones, which, in some places, are as much as 100 feet thick. In addition, these rocks are the source of supply for about 100 small springs and seeps.

\section{SEDIMENTARY ROCKS}

Sedimentary rocks of Paleozoic age cap the Grand Wash Cliffs and consist, in ascending order, of the Tonto Group (Gilbert, 1874) of Cambrian age and limestone of Devonian age (Twenter, 1962 , p. 10). Noble (1914, p. 61-65) named three formations in the Tonto Group - the Tapeats Sandstone, Bright Angel Shale, and Muav Limestone. The Paleozoic rocks do not yield significant amounts of water in the Grand Wash Cliffs; however, the rocks dip eastward, and water infiltrating them moves along the direction of dip out of the area and eventually emerges as springs in tributary canyons of the Colorado River on Hualapai Plateau (Twenter, 1962, p. 27-28).

\section{VOLCANIC ROCKS}

The volcanic rocks crop out in large areas near Kingman and in the Black Mountains, and are interbedded with alluvium in places in Hualapai and Sacramento Valleys. The rocks are divided into the older volcanic rocks of Mesozoic(?) and Cenozoic age, which include the Gold Road Latite of Ransome (1923, p. 15) and Wilson (1962, p. 53-54), and the younger volcanic rocks of Tertiary age. In some areas near the mountains, the younger volcanic rocks are interbedded with the alluvial deposits and yield some water to wells. 
Older Volcanic Rocks

The older volcanic rocks are composed of a thick sequence of andesite and latite flows and tuff beds, and they include some interbedded detrital deposits. The unit is several hundred feet thick in the Black Mountains. The older volcanic rocks form the main mass of the Black Mountains and crop out in isolated exposures in the Cerbat Mountains. The unit transmits some water through the fractured zones and interbeds of tuff; however, the unit is generally too fine grained or too tightly cemented to readily yield water to wells.

\section{Younger Voleanic Rocks}

The younger volcanic rocks consist of basalt flows, basaltic andesite flows and tuff, and rhyolite tuff and ignimbrites. The unit is exposed in isolated outcrops in and near the mountains, except in the Hualapai Mountains south of Walnut Creek. The younger volcanic rocks represent several major eruptions that occurred throughout much of middle and late Tertiary time (Cooley and others, 1967). Although the principal exposures are in the mountainous areas and along the margins of the basins, outcrops and logs of wells in the Hackberry area indicate that these rocks underlie, and are interbedded with, the older alluvium. The younger volcanic rocks also are interbedded with the older alluvium in an outcrop 5 miles southeast of Kingman. The unit underlies the alluvial deposits at Yucca and possibly elsewhere in Hualapai and Sacramento Valleys.

Piper and Poland (1943, p. 3-10) divided the younger volcanic rocks in the Kingman area into three units - basaltic rocks, rhyolitic rocks, and tuff and andesite(?) - and a summary of their description follows: Maximum thickness of the basalt is probably more than 1,000 feet, although only 835 feet is exposed; the basalt wedges out against the rugged surface of the underlying Precambrian rocks. The basaltic rocks include extrusive layers, separated by agglomerate bands and some banded or poorly stratified tuff. The extrusive layers are 10-120 feet thick, and the agglomerate bands are as much as 20 feet thick. The rhyolitic rocks are from 350 to 575 feet thick near Kingman, but south and east of Kingman they are generally thinner. The rhyolitic rocks include three types, which are, in ascending order, tuff (25-70 ft. thick), agglomerate (40-95 ft. thick), and porphyritic rhyolite (200-450 ft. thick). The tuff and andesite(?) unit crops out in only two small areas near Kingman and is probably about 200 feet thick.

The younger volcanic rocks are an aquifer at Kingman, where two large fault zones provide continuous passages for the storage 
and movement of water. A broad trough that plunges southeastward toward Kingman is cut by these fault zones, which intersect near the city ( $\mathrm{pl} .1$ ) and serve as barriers to water moving down the plunge of the trough (Piper and Poland, 1943). Two distinct ground-water reservoirs - one north of and one near the center of Kingman - are formed by the northwest and southwest angles of the fault zones (pl. 1). Piper and Poland (1943, p. 9) believed the ground-water reservoir north of Kingman to be larger and to contain more permeable material than the one near the center; however, well yields north of Kingman have declined rapidly in the last few years, and water levels fluctuate considerably with variations in precipitation. As a result, the municipal wells north of the city are seldom used, and the water supply is obtained from the younger volcanic rocks near the center of Kingman and from the older alluvium in Hualapai Valley. Only the upper 230 feet of the younger volcanic rocks at Kingman has been penetrated by wells, and as much as 1,400 feet of these rocks may underlie the water table. Although large yields probably could be obtained from wells drilled deeper into these rocks, long-term pumping would probably drain the aquifer.

A sequence of younger volcanic rocks similar to that at Kingman is present in the Grand Wash Cliffs, about 5 miles northeast of Hackberry. The sequence is composed of about 500 feet of basalt flows, tuff, and agglomerate overlain by discontinuous rhyolite flows and tuff as much as 70 feet thick. In this area, the younger volcanic rocks are topographically high and are drained of ground water.

In the Black Mountains the younger volcanic rocks consist of trachyte and rhyolitic tuff overlain by thin basaltic flows (Ransome, 1923, p. 16). About 20 springs issue from the base of the eastward-dipping rhyolitic tuff along the east side of the mountains; also, the tuff beds yield small amounts of water to a few wells in the area.

\section{ALLUVial Deposits}

Alluvial deposits of Tertiary and Quaternary age fill Hualapai and Sacramento Valleys to depths of several thousand feet and occur along canyon floors in the mountains. The deposits are divided into three major units - older, intermediate, and younger alluvium. The younger alluvium is divided into the piedmont, stream, and playa deposits. The alluvial deposits were divided on the basis of their lithologic and hydrologic properties, as determined by examination of outcrops and well cuttings from 10 wells 
in the area. The contacts, which were identified in well cuttings, are arbitrary and were placed on the basis of subtle lithologic changes.

\section{Older Alluvium}

The older alluvium of Tertiary age is the principal aquifer in Hualapai and Sacramento Valleys, and it yields moderate to large quantities of water to wells. The unit is the lowermost sedimentary deposit in the valleys, and it is exposed in isolated outcrops near the mountains. The older alluvium consists of moderately consolidated fragments of granite, schist, gneiss, and volcanic rocks in a brownish-gray silty clay or sandy matrix and contains interbeds of weakly consolidated tuff and agglomerate. Its composition reflects the nearby source areas in the surrounding mountains. The grain size decreases from pebble- and boulder-size fragments in the fanglomerate near the mountains to coarse sand and interbedded clay and silt in the valleys. The fanglomerate interfingers with the fine-grained deposits along the edges of both valleys. Younger volcanic rocks, cinders, and basalt flows are interbedded with, or underlie, the older alluvium near the mountains in the southern part of Hualapai Valley, in an outcrop in the Hualapai Mountains 5 miles southeast of Kingman, and near Yucca.

Where exposed, the older alluvium generally stands in vertical cliffs 10-50 feet high. The cliffs generally show some vertical fracturing and normal faulting; displacement is less than 1 foot, and the unit dips as much as $10^{\circ}$ to $15^{\circ}$.

Halite (common table salt) is present in the subsurface near the north end of Hualapai Valley. South of Red Lake, the KerrMcGee Corp. drilled two mineral exploration holes that penetrated more than 1,000 feet of halite from 1,450 to 2,600 feet below the land surface (Gillespie and others, 1966, p. 31-34). The age of the halite deposit is not known, but, because the deposit underlies about 1,000 feet of older alluvium, it is at least as old as the older alluvium and is probably contemporaneous with it. For purposes of this report, the halite is considered as part of the older alluvium. Halite deposits in Virgin and Muddy Valleys on the north side of the Colorado River in Nevada were tentatively assigned a Pliocene age (Longwell, 1928, p. 93-94) and are probably contemporaneous with the halite deposits in Hualapai Valley.

\section{Intermediate Alluvium}

The intermediate alluvium is probably Pleistocene and Tertiary in age and is exposed in discontinuous outcrops near the mountains and in small isolated patches in canyons in the mountains. The intermediate alluvium is an extensive near-surface 
deposit underlying the valley floors, where it is from 200 to 500 feet thick. The grain size decreases from pebble- and boulder-size fragments in the fanglomerate near the mountains to fine gravel, sand, and silt in the middle of the valleys.

The intermediate alluvium is composed predominantly of weakly to moderately consolidated fragments of granite, schist, gneiss, and volcanic rocks. A notable lithologic change occurs in the intermediate alluvium in several dissected alluvial fans along the west side of Sacramento Wash, west of Yucca. The fans are remnants of a once-continuous terrace that stood 50 to 100 feet above the present valley floor. Here, the intermediate alluvium consists of coarse angular fragments of basalt to basaltic andesite.

The intermediate alluvium is capable of transmitting and storing large quantities of ground water, but, because most of it lies above the water table in the area, it is not an important aquifer. Near the mountains, however, where it overlies bedrock at shallow depths, the intermediate alluvium is saturated, and wells yield as much as $50 \mathrm{gpm}$ of water.

\section{Younger Alluvium}

The younger alluvium covers extensive areas in Hualapai and Sacramento Valleys. It has been divided into piedmont, stream, and playa deposits on the basis of its lithologic properties and degree of cementation. The younger alluvium is Holocene in age, although some of the piedmont deposits are probably Pleistocene in age. The younger alluvium is generally above the water table, except in some of the mountain canyons, where the stream deposits yield small amounts of water to wells.

Piedmont deposits. - The piedmont deposits consist of poorly consolidated silt- to gravel-size fragments of granite, schist, gneiss, and volcanic rocks, and overlie terraces, alluvial fans, piedmont slopes, and valley floors. Although the unit generally is poorly consolidated, local calcium carbonate cementation has formed caliche layers. The piedmont deposits are as much as 50 feet thick and overlie the intermediate and older alluvium. Grain size of the deposits ranges from silt to boulders. The piedmont deposits are not known to yield water to wells in the area.

Stream deposits. - The stream deposits consist of unconsolidated sand- and gravel-size fragments of granite, schist, gneiss, and volcanic rocks. Caliche layers are present in places in the deposits. The unit occurs in streambeds and is probably not more than a few feet thick in most places. The stream deposits yield small amounts of water to wells in the mountain canyons, where they are underlain by impermeable bedrock at shallow depths. 
Playa deposits. - Playa deposits occur only at Red Lake, at the north end of Hualapai Valley. The playa at Red Lake - the second largest playa in Arizona - covers an area of about 22 square miles. The playa deposits consist of unconsolidated silt and clay and small amounts of sand- and fine gravel-size fragments of granite, schist, and gneiss. The thickness of the unit is not known; however, the unit is above the water table and does not yield water to wells.

\section{SEISMIC SURVEYS}

Two seismic surveys were made in Sacramento Valley and one was made in Hualapai Valley to measure the thickness of the alluvial deposits. (See pl. 1 for location of seismic profiles.) The surveys were made, under the direction of R. H. Godson, by the Branch of Astrogeology of the U.S. Geological Survey.

Conventional refraction methods were used, in which geophones placed at equal distances along seismometer spreads recorded arrival times of the shot impulses. The vertical-velocity gradient of the geologic section is not known, and the computed depths may be in error if the refracting velocities are not similar to the vertical velocity throughout the geologic section. The individual velocity layers were not identified by rock type, other than in very general terms. An accurate interpretation of seismic data in terms of rock type is difficult to obtain because of the wide range in velocities possible in sedimentary and igneous material and because of the overlap in the velocities with which the seismic waves travel in the materials. According to Pakiser, Press, and Kane (1960), velocities in granitic and metamorphic rocks range from 15,000 to $17,750 \mathrm{fps}$ (feet per second), and the rock layers having velocities within this range can be identified with reasonable certainty. However, the seismic velocities for layers of evaporites and basalt and rhyolite flows may also be within this range.

Seismic profile 1 (pl. 2) was shot across Hualapai Valley, north of Red Lake. Three seismic spreads, 8,500 feet long and consisting of 24 equispaced seismometers, were recorded. The eastern spread was recorded from shots at both ends of the spread. Recordings of the western and center spreads were made from shots in the middle of each spread and from shots that were offset 8,500 feet to the east. The size of the dynamite charges ranged from 50 to 300 pounds, depending on the distance from the shot to the end of the spreads. The first, or upper, layer of profile 1 was interpreted as a layer in which velocity increases with depth. The velocity near the surface is about $2,800 \mathrm{fps}$ in the center of the profile and about $3,900 \mathrm{fps}$ at the west end of the profile; the 
velocity increases with depth to about $5,000 \mathrm{fps}$. The average velocity of the upper layer is $3,600 \mathrm{fps}$. This upper layer is probably equivalent to the alluvial deposits that lie above the water table. A computed depth of 615 feet for the base of this layer in the middle of the western spread compares favorably with a 655foot water level in a well at this location. A velocity of 9,400 fps was used to compute the thickness of the second layer, which probably is equivalent to the saturated alluvium. At the east and west ends of the profile, intermediate velocities of 15,400 and $12,000 \mathrm{fps}$, respectively, were recorded, which probably represent halite or volcanic rocks, or both. The true velocity of this layer could not be determined, and the layer was ignored in computing the depth to basement rock. The lowermost, or 15,900 fps, layer has a steep slope at the east end of the profile, is relatively level in the center, and has a moderate slope at the west end. The steep slope is probably due to rock displacement along the Grand Wash fault; vertical displacement is at least 1,700 feet.

Profile 2 (pl. 2) was shot by means of three spreads that were spaced at 8,500-foot intervals across the middle of Sacramento Valley. The number of geophones, length of spreads, and charge sizes were the same as those used for profile 1 . The eastern and center spreads were recorded from shots on both ends of each spread. In addition, the center spread was recorded from a shot offset 7,400 feet to the west. The eastern spread was shot from in the middle and from offset distances of 8,500 feet from each end of the spread. The first layer of profile 2 is alluvium that is generally about 600 feet thick and that has an average velocity of 4,950 fps. Although the base of this layer does not coincide with the water table, as indicated by a depth-to-water measurement of 738 feet in a well near the center of the profile, it may be coincident with a former water table (R. H. Godson, written commun., 1966). No significant lithologic break in the 400 - to 600 -foot depth range is apparent in cuttings from the Duval wells, 3 miles to the north. The second layer ranges in velocity from 10,200 to 12,200 fps. These velocities were used to compute the depth between the first layer and the lowermost, or the $17,500 \mathrm{fps}$, layer. The fact that the uppermost 800 feet of the second layer is alluvium, as seen in well cuttings from the Duval wells, does not preclude the possibility that other rock types, such as volcanic rocks or evaporite deposits, may be present at depth. The lowermost, or 17,500 fps, layer is equivalent to the basement rock and is relatively shallow at both ends of the profile. In the center of the profile, it is at a depth of 4,400 feet. The depth and configuration of this layer is estimated in the intervals between the spreads. 
Profile 3 (pl. 2) was shot by use of two 8,500-foot spreads and one 7,000-foot spread south of Yucca in Sacramento Valley. The spreads were recorded from shots on both ends of each spread. The size of the dynamite charges was 100 pounds for all shots, except for one 80-pound charge. The first layer of profile 3 is about 325 feet thick and has a velocity of 4,000 fps. The thickness corresponds to the unsaturated alluvium, as indicated by measurements of water levels in several nearby wells. The second layer has velocities of 7,150 and 8,300 fps at the west and east ends, respectively, of the center spread. This layer pinches out to the east against the basement rocks (fourth layer) and to the west against the volcanic rocks (third layer). The third layer has a velocity of $11,800 \mathrm{fps}$ and is equivalent to the younger volcanic rocks that crop out about 200 feet west of the profile; the layer slopes downward to a depth of between 700 and 1,000 feet below the center spread. The layer was not observed below the eastern spread. The fourth layer has a velocity of $16,000 \mathrm{fps}$ and slopes from the surface at the east end of the profile to a depth of 750 feet in the middle of the eastern spread. The fourth layer is equivalent to the igneous and metamorphic rocks that crop out at the east end of the profile. The layer was not observed below the center and western spreads.

\section{STREAMFLOW}

Streamflow is that part of precipitation that appears in natural channels. Overland flow to stream channels occurs only when the rate of rainfall or snowmelt exceeds the rate of infiltration. When the infiltration rate is exceeded, the excess water moves overland, by sheetflow, and collects in the small channels, which are tributary to the main channels of the drainage basins. Streamflow from the mountain canyons flows out onto the dissected alluvial fans and onto the valley floors. Downstream from the points where the streams emerge from the canyons, the flows are diminished by infiltration of the water into the streambeds and by evapotranspiration. Streamflow losses are depicted by the geometry of the stream channels. In the mountains, the cross-sectional areas of the channels generally become larger downstream. As the streams flow onto the dissected alluvial fans, the cross-sectional areas of the channels decrease. For example, many stream channels in Hualapai Valley lose their identity before they reach Truxton Wash or the playa at Red Lake.

The streambeds in the mountains are composed mostly of coarse sand and gravel; bedrock occurs at shallow depths in the streambeds and crops out in places. The streambeds in the valleys 
are composed mainly of sand and are wide and shallow. Some of the water leaves the mountains as ground water, and some leaves as streamflow. If the streams flowed over bedrock at the base of the mountains, however, all the water would reach the valley floors as streamflow. Streamflow occurs in the channels cut in the valley floors following short-duration, high-intensity storms or cloudbursts; however, this type of streamflow is erratic in occurrence and in duration and provides only a small part of the total flow in the report area. Although a few streams in the Hualapai Mountains are perennial, the streams in the two valleys are ephemeral, for the amount of precipitation received on the valley floors is small, and the loss of water to infiltration and evapotranspiration is large.

Hualapai Valley is an area of closed surface drainage and includes a small tributary valley at Hackberry. Truxton Wash, the principal stream in Hualapai Valley, drains into the playa at Red Lake. Although substantial streamflow occurs in the mountains as a result of high-intensity storms, the flow seldom reaches the middle of Hualapai Valley and only occasionally reaches Red Lake, where most of the inflow to the lake is lost to evaporation.

One continuous gaging station and two partial-record stations were maintained on Truxton Wash from 1964 to 1967 . Only two major flows - 1,120 cfs on December 10, 1965, and 1,960 cfs on August 18, 1966, at Truxton Wash at Valentine gaging station occurred during the period of record (table 1 ). The maximum peak known was on August 2, 1904, when a flow of 49,000 cfs occurred in Truxton Canyon (Murphy and others, 1905, p. 118).

Winter and summer floods differ because of the differences in storm types. The flood of December 10, 1965, caused by rain falling on snow, was of long duration, and the flow reached Red Lake. The flood of August 18, 1966, the result of a high-intensity thunderstorm, was of short duration, and the flow did not reach Red Lake. The peak discharge for the December 10, 1965, flood decreased downstream from $1,120 \mathrm{cfs}$ at Truxton Wash at Valentine to 753 cfs at the Truxton Wash No. 1 near Hackberry gage and decreased to $520 \mathrm{cfs}$ at the Truxton Wash No. 2 near Hackberry gage (table 1). The estimated total discharge from the December 10, 1965, flood was 600 acre-feet at Truxton Wash at Valentine. The estimated peak discharge for the August 18, 1966, flood decreased from 1,960 cfs at Valentine to $753 \mathrm{cfs}$ at Truxton Wash No. 1 and decreased to $402 \mathrm{cfs}$ at Truxton Wash No. 2. The estimated total discharge from the August 18 flood was 100 acre-feet at Truxton Wash at Valentine (fig. 4). 
TABLE 1.-Peak discharges at gaging stations on streams in Hualapai and Sacramento Valleys and adjacent areas

[See plate 1 for gaging-station number and location. Altitude datum is mean sea level. E, estimated]

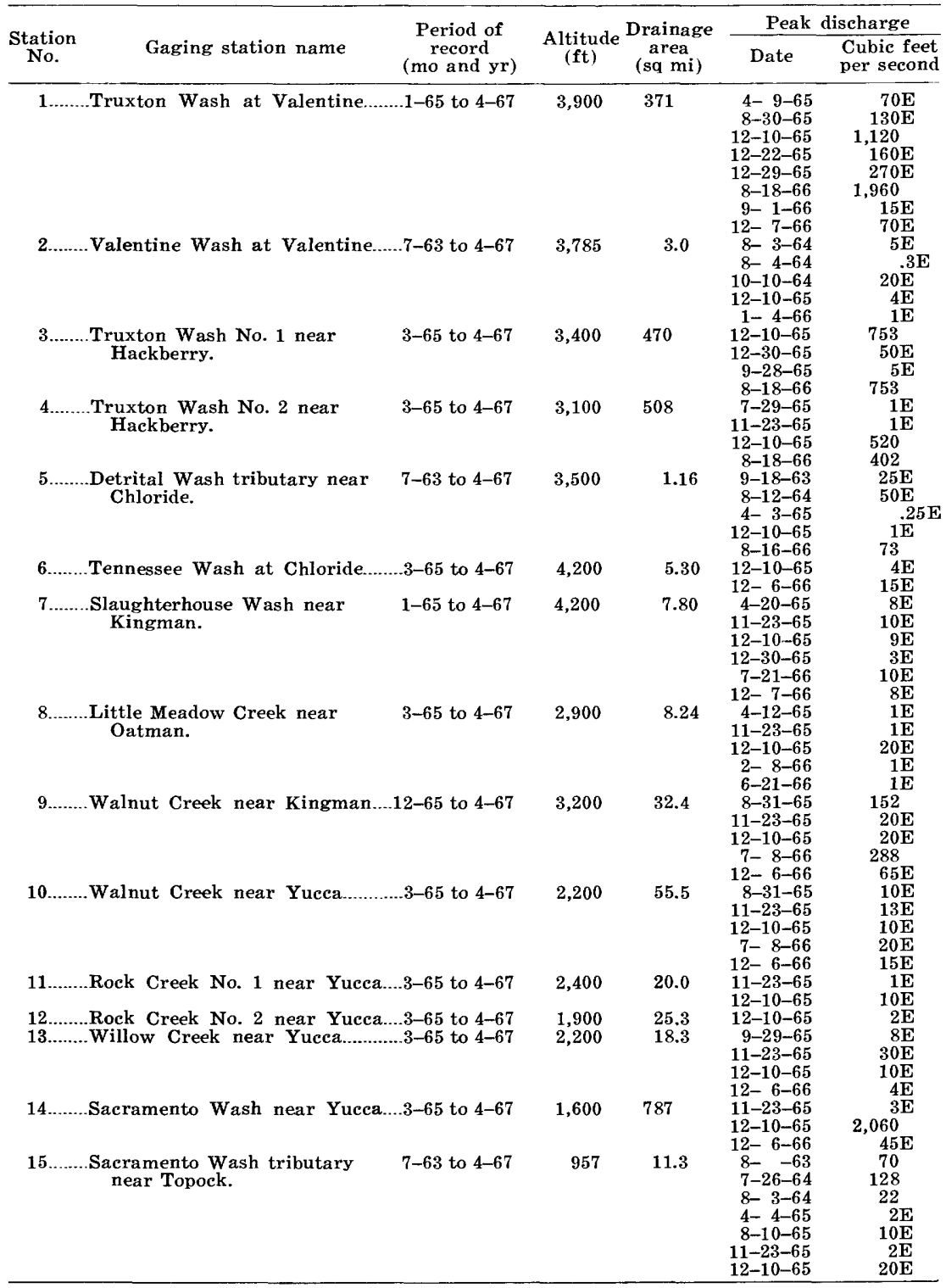

Sacramento Valley is drained by Sacramento Wash, which joins the Colorado River near Topock, Ariz. A large flood occurred in Sacramento Wash on August 2, 1904 ; a bridge and 600 feet of railroad 5 miles south of Yucca were destroyed (Murphy and others, 1905, p. 118). On September 6, 1939, a peak flow of 15,000 


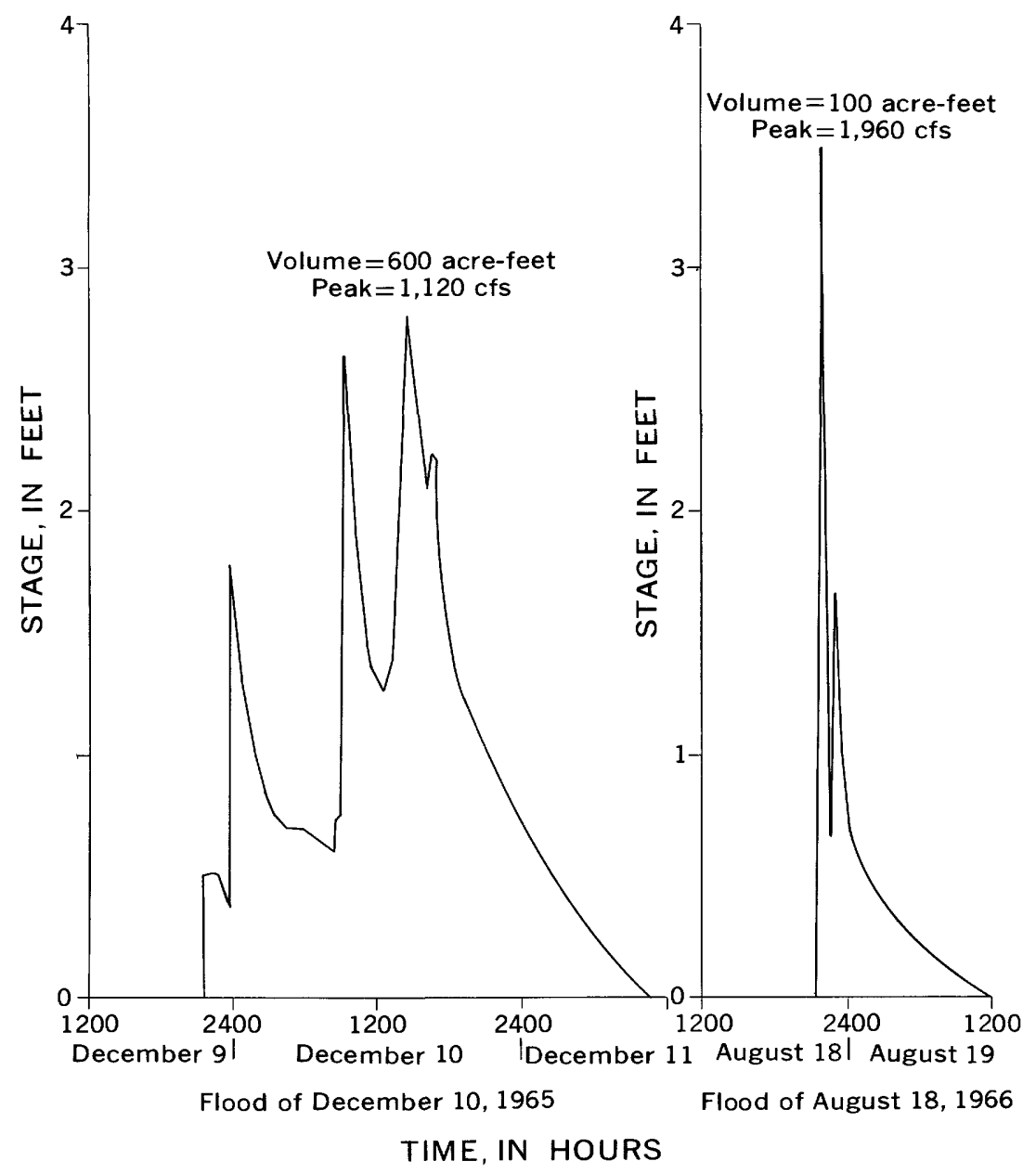

Figure 4. - Flood stage at Truxton Wash at Valentine gaging station. Cfs, cubic feet per second.

cfs occurred in Sacramento Wash at its mouth (Smith and Heckler, 1955, p. 5). Only one major flood occurred at the Sacramento Wash near Yucca gaging station during the period of record 1965-67. The flood occurred on December 9-10, 1965; the peak discharge was 2,060 cfs, and the volume of flow was about 1,200 acre-feet. During this storm, many of the tributaries flowed that were ordinarily dry; most of the tributary flow originated in streams draining the Black Mountains.

During short-duration storms, very little runoff reaches Sacramento Wash. For example, in August 1965 and in July 1966 peak flows of 152 and $288 \mathrm{cfs}$, respectively, were recorded at the 
gage on Walnut Creek near Kingman; whereas, estimated peak flows of 10 and $20 \mathrm{cfs}$, respectively, occurred about 10 miles farther downstream at the gage on Walnut Creek near Yucca; however, these flows did not reach Sacramento Wash 2 miles farther downstream.

Because no long-term streamflow records are available, the mean annual surface-water inflow into Hualapai and Sacramento Valleys was estimated by using two methods developed by Moore (1968). These methods - regional runoff-altitude relations and channel geometry - had been used successfully in Nevada to estimate mean annual runoff (Moore, 1968). The first method is based on the assumptions that precipitation and runoff are directly related to altitude and that any two areas that have the same precipitation-altitude relation also will have about the same runoffaltitude relation. The other method is based on the geometry selected widths and depths - of the low-flow channels of the streams. These two methods give only approximate values of mean annual runoff. The method developed by Hely and Peck (1964) for estimating runoff in the lower Colorado River basin, of which Sacramento and Hualapai Valleys are a part, was not used. Their method does not include an adjustment for infiltration losses in the stream channels and is not applicable to those areas where a large part of the runoff from the mountains is lost by streamflow infiltration to the highly permeable channel materials.

By use of Moore's method, the annual runoff onto the floor of Hualapai Valley is estimated to be about 4,000 acre-feet, of which 1,500 acre-feet is from Truxton Wash and 2,500 acre-feet is from the 388-square-mile mountain area below Truxton Canyon, immediately adjacent to the valley floor. The estimated runoff from the 322-square-mile adjacent mountain area onto the floor of Sacramento Valley is about 2,000 acre-feet per year. These are estimates of the annual runoff that reaches the valley floors after infiltration losses to stream alluvial deposits, which extend far up into the mountains. The estimated mean annual flow at the gage at Sacramento Wash near Yucca is about 400 acre-feet, which corresponds favorably to the mean discharge of 500 acre-feet computed from the short period of streamflow record (4 years) at the site. Although the period of record at Yucca is too short to allow computation of an accurate average annual discharge rate, the close agreement with the values obtained by the methods of estimating runoff indicates that the measured average annual runoff of 500 acre-feet at the station also is reasonable as an estimate for a longer period. 


\section{INFILTRATION OF STREAMFLOW}

Recharge to the alluvial deposits, the major aquifer in the area, is mostly from infiltration of streamflow. Most of the recharge occurs near the apexes of the dissected alluvial fans, which extend into the mountain canyons. Streamflow infiltrates the fan deposits, and the water moves downslope through the fan deposits to the major aquifer in the valleys. Recharge from precipitation on the valley floor is negligible because of the generally high evapotranspiration rate and because of the presence of relatively impervious layers of clay and caliche near the land surface.

A small amount of water probably enters Sacramento Valley from the west side of the Black Mountains by percolation through the permeable layers of the easterly dipping volcanic rocks. The water emerges as springs along the base of the east slope of the Black Mountains, or it directly infiltrates the alluvium.

Under natural conditions, the long-term ground-water recharge in a basin is equal to the ground-water discharge. Except in the Hackberry area, the natural conditions probably have not been affected by pumping, and ground-water recharge is approximately equal to the estimated subsurface outflow of about 9,000 acre-feet per year from Hualapai and Sacramento Valleys. (See section entitled "Subsurface Outflow.")

\section{GROUND WATER}

\section{MOVEMENT}

The general movement of ground water is from the mountains to the valleys and downgradient to the Colorado River (pl. 1). Ground water moves southwestward from Truxton Canyon into the Hackberry area. Under natural conditions, some ground water moved from the Hackberry area northward over a shallow bedrock barrier into the main part of Hualapai Valley, and some moved southward into Big Sandy Valley. In this area the ground-water divide is north of the topographic divide. Recent pumping in the Hackberry well field has lowered water levels such that little or no ground water now flows into the main part of Hualapai Valley from Hackberry. In Hualapai Valley, ground water moves northward, flows under the playa at Red Lake, and finally enters the Colorado River at the upper end of Lake Mead. In Sacramento Valley, ground water moves southward at a gradient ranging from about 8 feet per mile in the northern part of the valley to about 20 feet per mile in the southern part of the valley and then moves westward past the south end of the Black Mountains to the Colorado River. 
DEPTH TO WATER

The depth to water in the main part of Hualapai Valley ranges from 260 feet below land surface at Red Lake to about 900 feet below land surface at the south end of the valley. In the Hackberry area, the depth to water ranges from about 70 feet at Hackberry to about 150 feet in the Hackberry well field. The water level ranges in altitude from about 2,400 feet (datum is mean sea level) north of Red Lake to about 3,200 feet near Kingman at the south end of the valley (pl. 1).

The depth to water in the main part of Sacramento Valley ranges from less than 300 feet below land surface south of Yucca to more than 1,000 feet below land surface at the north end of the valley. The depth to water in the younger volcanic rocks at Kingman ranges from about 100 to 125 feet below land surface. The water level ranges in altitude from less than 1,500 feet (datum is mean sea level) south of Yucca to more than 1,800 feet at the north end of the valley.

\section{AQUIFER CHARACTERISTICS}

The older alluvium is the principal aquifer in Hualapai and Sacramento Valleys; however, the younger volcanic rocks are an aquifer at Kingman. To determine aquifer characteristics, pumping tests were made at selected wells in Hualapai and Sacramento Valleys. The hydrologic characteristics determined from the well data are summarized in table 2.

About 20 wells have been drilled in the main part of Hualapai Valley - two irrigation wells, one Kingman municipal well, one industrial well, two private water company wells, six stock wells, and at least seven U.S. Army test wells that were abandoned at the end of World War II. The discharge rates of the wells tested in the main part of Hualapai Valley - (B-22-16) 26bac and (B26-17) 35aaa - ranged from 660 to $1,500 \mathrm{gpm}$. Specific capacities ranged from 11.2 to $12.9 \mathrm{gpm}$ per foot of drawdown. Transmissibility of the aquifer at the tested wells throughout the valley ranged from 22,000 to 44,000 gpd (gallons per day) per foot. The coefficient of transmissibility of the aquifer is defined as the rate of flow, in gallons per day, through a vertical strip of the aquifer 1 foot wide and extending the full saturated height of the aquifer under a hydraulic gradient of 100 percent - that is, transmissibility equals the permeability multiplied by the saturated thickness of the aquifer (Ferris, 1955). In wells where the coefficient of transmissibility could not be determined from the pumping-test data, the coefficient was estimated by multiplying the specific capacity by a coefficient determined from wells for which both 


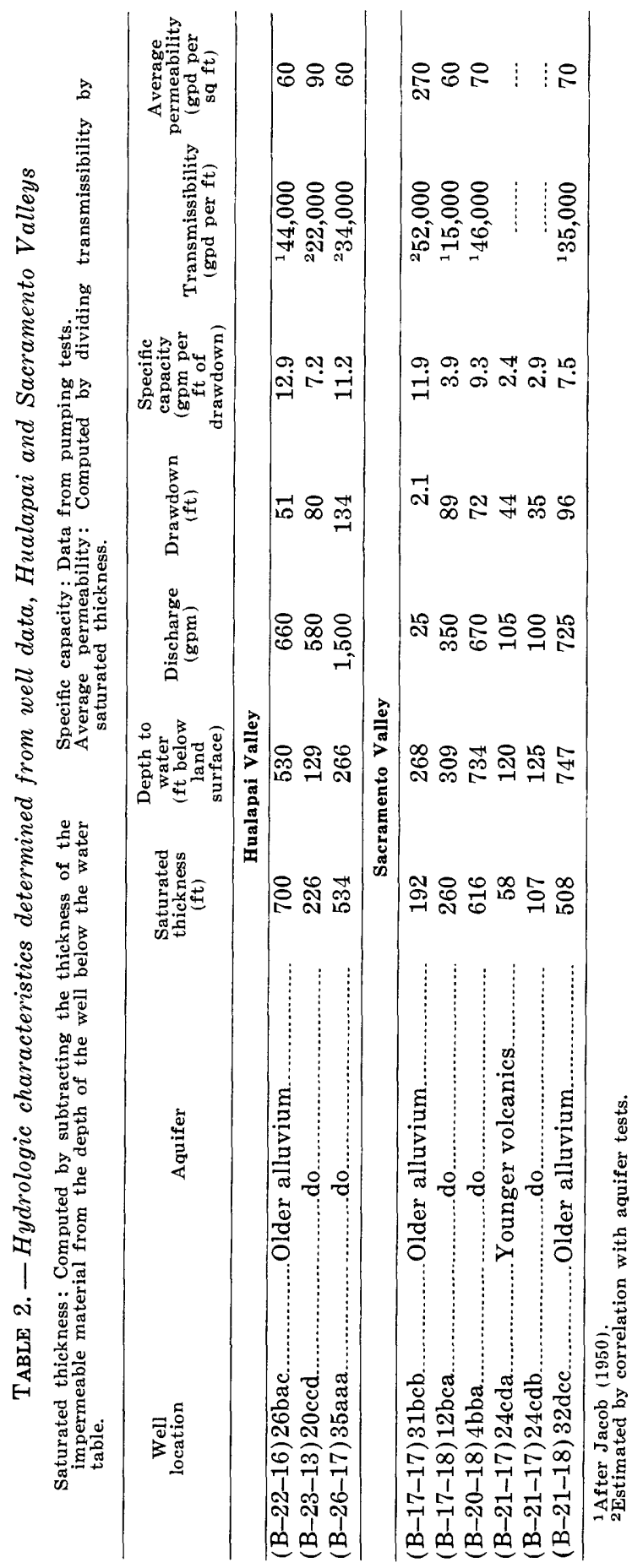


specific capacity and transmissibility data were available. The coefficients of proportionality are 3,000 for Hualapai Valley and 4,400 for Sacramento Valley. The coefficients are considerably higher than the average coefficient of 2,000 obtained for central Arizona (Anderson, 1968, p. 9). Because specific capacities are dependent on the construction and performance characteristics of the wells and on the aquifer characteristics, the wells tested in Hualapai and Sacramento Valleys were proved to be not so efficient as those in central Arizona. The permeability of the aquifer (including both valleys) at the tested wells ranged from 60 to $270 \mathrm{gpd}$ per square foot. The coefficient of permeability is defined as the rate of flow of water, in gallons per day, through a cross-sectional area of 1 square foot, under a hydraulic gradient of 1 foot per foot.

At Hackberry, where Truxton Wash flows through a narrow gorge before it emerges into the main part of Hualapai Valley, the alluvium is only 80 feet thick. To the southeast in the Hackberry well field, the alluvium overlying the consolidated rocks is about 1,000 feet thick. Several low-yield domestic, stock, and railroad wells have been drilled in and near Hackberry during the last 50 years. At least eight wells were drilled by the Army east and southeast of Hackberry during World War II to supply water to an Army Air Corps gunnery school near Kingman. Three wells in the Hackberry well field furnish part of the municipal water supply for Kingman; two are former Army wells. During a pumping test, well (B-23-13)20ccd yielded $580 \mathrm{gpm}$, and the specific capacity was $7.2 \mathrm{gpm}$ per foot of drawdown. The transmissibility of the aquifer was estimated to be $22,000 \mathrm{gpd}$ per foot, and the average permeability was $90 \mathrm{gpd}$ per square foot (table 2 ).

Several railroad and domestic wells yielding small discharge have been drilled in Sacramento Valley near Yucca. In the main part of the valley north of Yucca, eight wells have been drilled in the older alluvium, and five of these are in the Duval Corp. well field. The discharge rates of wells tested in the main part of Sacramento Valley ranged from 25 to $725 \mathrm{gpm}$; specific capacities ranged from 3.9 to $11.9 \mathrm{gpm}$ per foot of drawdown. Transmissibilities ranged from 15,000 to $52,000 \mathrm{gpd}$ per foot. Average permeabilities ranged from 60 to $270 \mathrm{gpd}$ per square foot (table 2).

More than 100 domestic and public-supply wells have been drilled in the younger volcanic rocks at Kingman. Of these, about 20 are still in use. The discharge rates of wells (B-21-17)24cda and (B-21-17) 24cdb were 105 and $100 \mathrm{gpm}$, respectively, and the specific capacities were 2.4 and $2.9 \mathrm{gpm}$ per foot of drawdown, respectively. The transmissibility and the average permeability of the younger volcanic rocks were not determined. 
STORAGE

The older alluvium is the storage reservoir for virtually all the usable ground water in Hualapai and Sacramento Valleys. The amount of ground water in storage was estimated for the saturated part of the alluvium above a depth of 1,500 feet below the land surface, or above the consolidated rocks, whichever was shallower, except for the northern part of Hualapai Valley. In this part of the area, a depth limit of 1,000 feet below land surface was used because of the presence of evaporite deposits at depths of 1,450 feet at Red Lake. The depth and the saturated thickness of the alluvium were determined from seismic profiles (pl. 2), well logs, and water-level measurements. In Sacramento Valley the ground-water reservoir has an areal extent of 310 square miles, and in Hualapai Valley it has an areal extent of 460 square miles. An average specific yield of 5 to 10 percent was estimated for the older alluvium; the range of the calculated volume of ground water in storage to the depths described is from 10.5 to 21 million acre-feet in Hualapai Valley and from 6.5 to 13 million acre-feet in Sacramento Valley. The estimated volume of ground water in storage in the younger volcanic rocks at Kingman is about 300,000 acre-feet.

\section{DISCHARGE}

Springs

About 130 springs and seeps are present in Hualapai and Sacramento Valleys. Most of the springs issue from the igneous, metamorphic, and volcanic rocks in the mountain areas, and no springs are known to issue from the alluvium on the valley floors. The median spring discharge is about $2 \mathrm{gpm}$, and an estimated 950 acre-feet of water per year is discharged by the springs. About half the water is used by ranchers, mainly for livestock. Probably less than one-fourth of the annual spring discharge is recharged to the ground-water reservoir in the valleys; the rest is lost to the atmosphere through evapotranspiration.

\section{Wells}

The amount of water pumped in Hualapai Valley prior to 1960 averaged about 20 acre-feet per year. The Hackberry well field was put into operation in 1960, and the annual pumpage had increased to 1,000 acre-feet per year by 1962 . In 1964 water pumped for irrigation increased the pumpage to 2,000 acre-feet per year; by 1967 , the amount had increased to 3,600 acre-feet per year because of an increase in irrigated acreage and the completion of a new Kingman municipal well in the main part of the valley. 
In Sacramento Valley, the amount of water pumped prior to 1961 was about 250 acre-feet per year, most of which was pumped from the municipal wells in Kingman. In 1961 the pumpage decreased to 130 acre-feet per year because of the additional water supply developed for Kingman in Hualapai Valley. In 1964 the Duval Corp. well field began production, and pumpage in the valley increased to 440 acre-feet and to 3,800 acre-feet in 1965. In 1967, 4,200 acre-feet of water was pumped in Sacramento Valley.

\section{Subsurface Outflow}

Subsurface outflow from Hualapai Valley occurs at two places - north of Red Lake and southeast of Hackberry. The annual subsurface outflow from Hualapai Valley is estimated to be about 5,000 acre-feet. The amount of outflow southeast of Hackberry was estimated for natural conditions, which existed before pumping began in the Hackberry well field. Subsurface outflow leaves Sacramento Valley south of Yucca and is estimated to be about 4,000 acre-feet per year (table 3 ).

TABLE 3.-Estimated subsurface outflow from Hualapai and Sacramento Valleys

\begin{tabular}{|c|c|c|c|c|}
\hline Location & $\begin{array}{l}\text { Width of } \\
\text { aquifer } \\
\text { cross } \\
\text { section } \\
\text { (ft) }\end{array}$ & $\begin{array}{l}\text { Average hydraulic } \\
\text { gradient through } \\
\text { the cross section } \\
\text { (ft per } \mathrm{ft} \text { ) }\end{array}$ & $\begin{array}{c}\text { Estimated } \\
\text { average } \\
\text { coefficient of } \\
\text { trans- } \\
\text { missibility } \\
\text { (gpd per ft) }\end{array}$ & $\begin{array}{l}\text { Estimated } \\
\text { outflow } \\
\text { (acre-ft } \\
\text { per yr) }\end{array}$ \\
\hline \multicolumn{5}{|l|}{ Hualapai Valley: } \\
\hline North of Red Lake.................... & 22,000 & $100: 30,000$ & 50,000 & 4,000 \\
\hline Southeast of Hackberry..... & 10,000 & 25: 5,000 & 22,000 & 1,000 \\
\hline Total, Hualapai Valley... & $\ldots \ldots \ldots$ & $\ldots \ldots \ldots$ & $\ldots \ldots \ldots$ & 5,000 \\
\hline $\begin{array}{l}\text { Sacramento Valley: } \\
\text { South of Yucca.. }\end{array}$ & 17,000 & $100: 30,000$ & 60,000 & 4,000 \\
\hline $\begin{array}{l}\text { Total, Hualapai and } \\
\text { Sacramento Valleys.... }\end{array}$ & ......... & .......... & .......... & 9,000 \\
\hline
\end{tabular}

The quantity of water moving through an aquifer at any given place is directly related to the transmissibility of the aquifer, the hydraulic gradient, and the width of the cross section through which the water is moving. The estimated transmissibilities were adjusted for the total saturated thickness of the aquifers and were based on pumping tests (table 2 ), specific capacities of wells, drillers' $\operatorname{logs}$, lithologic $\operatorname{logs}$, and seismic profiles. The hydraulic gradient at each of the outflow points was determined from the water-table contours ( $\mathrm{pl} .1$ ), and the cross-sectional widths were determined from the seismic profiles (pl. 2) and from topographic maps. 


\section{WATER-LEVEL FLUCTUATIONS}

The static water level in an abondoned Army well, (B-24-14) $28 \mathrm{dbc}$, in Hualapai Valley has declined about 2 feet per year since 1952 (fig. 5), probably because of pumping at Hackberry. Elsewhere in the main part of Hualapai Valley, water levels have remained almost unchanged, except for slight fluctuations due to

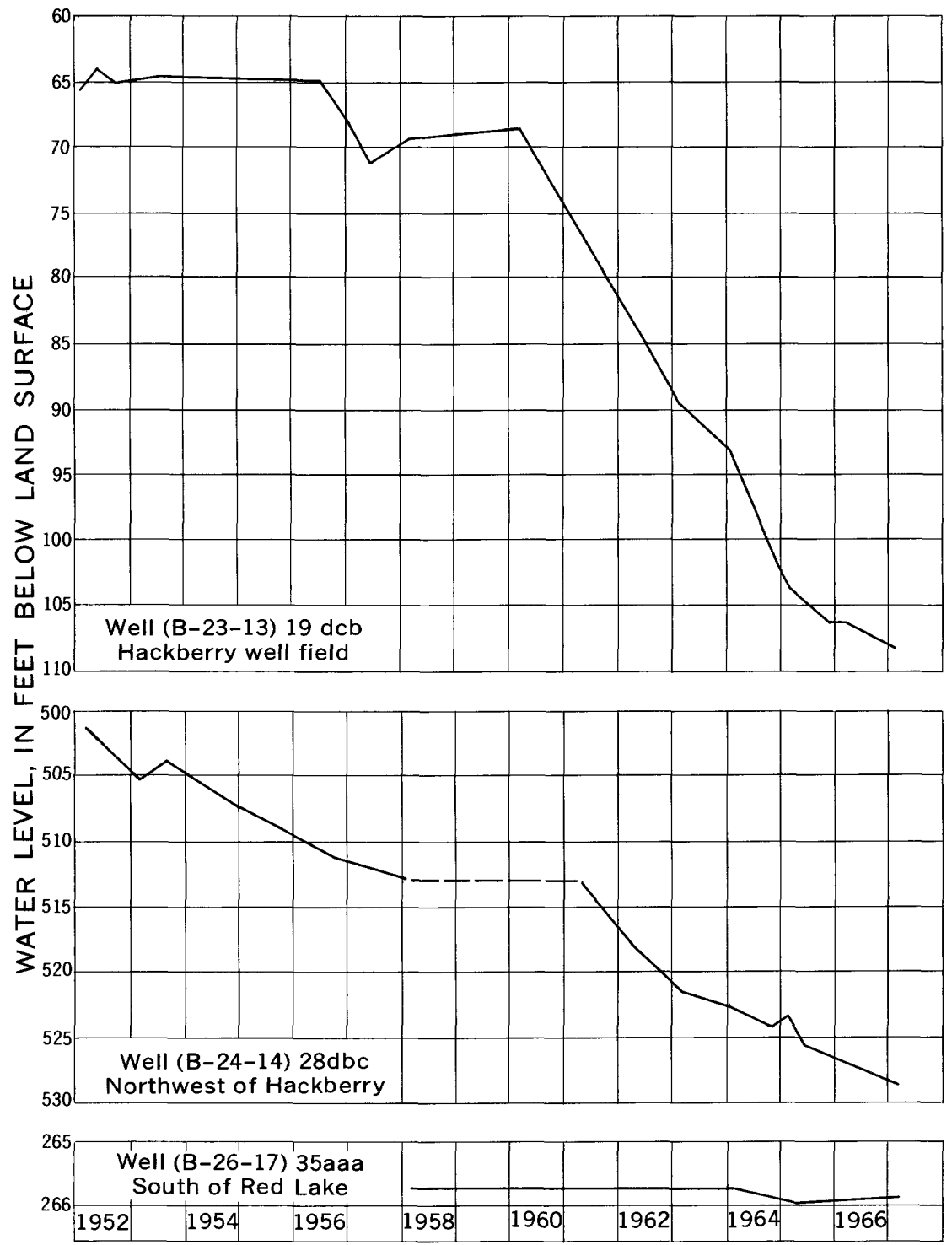

Figure 5. - Water levels in selected wells in Hualapai Valley. 
barometric effects. The static water level at the Hackberry well field declined an average of about half a foot a year for at least 10 years prior to 1960 . Between 1960 and 1965, extensive pumping of the Kingman municipal wells resulted in an annual decline of from 5 to 7 feet. Since 1965, production from the municipal wells has been reduced about 50 percent, and the rate of waterlevel decline has decreased and is about 1-21/2 feet per year (fig. 5).

Water levels in wells in the main part of Sacramento Valley have remained fairly constant, except in the Duval Corp. well field. The Duval Corp. well field was put into operation in 1964; static water levels declined 12 to 14 feet between October 1964 and February 1967 - an average decline of 5.8 feet per year. Water levels in wells within 3 miles of the well field have not been affected by the withdrawal. From 1953 to 1963 static water levels at Kingman [well (B-21-17)24cda] declined nearly 1 foot per year. Since 1963, water levels have risen about half a foot per year because of the decrease in pumping at Kingman. In the Kingman well field water levels fluctuate 4 to 5 feet annually in well (B-21-17) 24cdd, declining during the summer and rising during the winter (fig. 6).

\section{QUALITY OF WATER}

The ground water in the report area generally is of good chemical quality, but in some areas in and near the mountains, the water is highly mineralized. Well (B-21-15) 33bbb and the four wells in secs. 3 and 9, T. 23 N., R. 18 W., are near mineralized areas in the Hualapai and Cerbat Mountains; water samples from these wells contained from 1,430 to $2,365 \mathrm{mg} / \mathrm{l}$ (milligrams per liter) total dissolved solids. The concentration of dissolved solids is a measure of the total quantity of dissolved mineral matter in the water. In general, the suitability of water for most uses decreases with an increase in its mineral content. The U.S. Public Health Service (1962) has recommended that water for drinking purposes should contain no more than $500 \mathrm{mg} / \mathrm{l}$ of dissolved solids. Water containing as much as $1,000 \mathrm{mg} / \mathrm{l}$, however, can be used if better water is not available. The chemical analyses of water samples from wells given in table 4 are representative of the quality of water that occurs in the igneous and volcanic rocks and in the alluvial deposits in Hualapai and Sacramento Valleys.

The following discussion refers only to the water from wells that penetrate the older alluvium beneath the valley floors and the younger volcanic rocks at Kingman and is not applicable to the highly mineralized water mentioned previously. In general, the quality of water from the older alluvium and the younger 

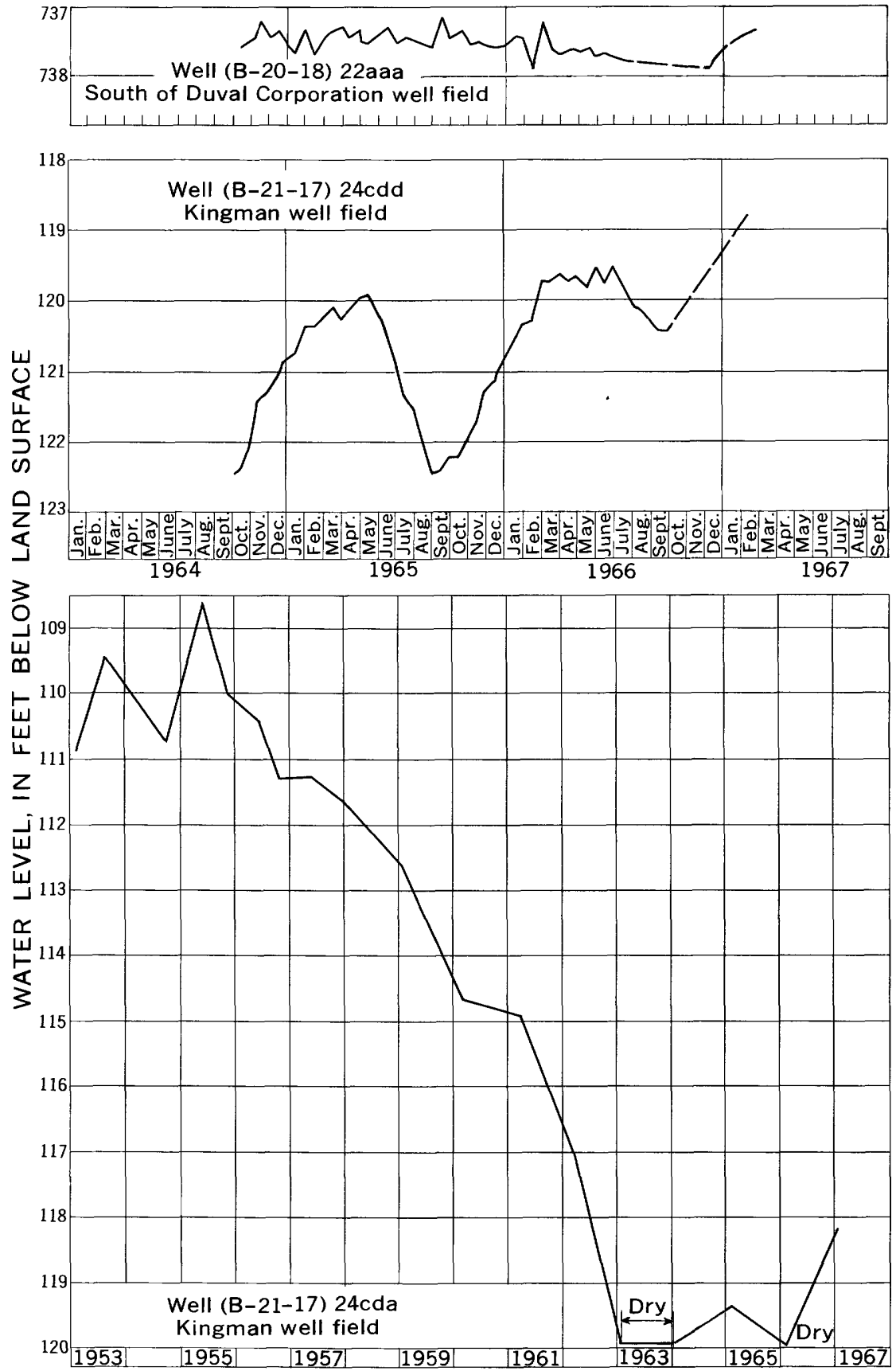

FiguRE 6. - Water levels in selected wells in Sacramento Valley. 
volcanic rocks meets the standards set by the U.S. Public Health Service (1962) for drinking water on interstate carriers.

As the ground water moves northward through Hualapai Valley, the total dissolved-solids content increases, and the type of water changes from sodium calcium bicarbonate to sodium chloride. The median concentration of dissolved solids in water from the older alluvium in Hualapai Valley is $379 \mathrm{mg} / \mathrm{l}$; concentrations range from $195 \mathrm{mg} / \mathrm{l}$ in water from wells at the south end of the valley near Kingman to $1,200 \mathrm{mg} / \mathrm{l}$ in water from wells north of Red Lake. The marked increase in the dissolved-solids content of the ground water near Red Lake is due to the presence of evaporite deposits.

In Sacramento Valley, the ground water from the mineralized area along the west side of the Cerbat Mountains has a high dissolved-solids content. As the ground water moves southward in the valley, however, the dissolved-solids content decreases because of dilution by recharge from streams. The median concentration of dissolved solids in the water from the older alluvium in Sacramento Valley and the younger volcanic rocks at Kingman is $348 \mathrm{mg} / \mathrm{l}$; concentrations range from 291 to $475 \mathrm{mg} / \mathrm{l}$.

The hardness of water is caused mainly by calcium and magnesium. According to Collins, Lamar, and Lohr (1934, p. 17-18), water having a hardness of less than $60 \mathrm{mg} / \mathrm{l}$ is "soft"; that having a hardness between 61 and $120 \mathrm{mg} / \mathrm{l}$ is "moderately hard"; that having a hardness between 121 and $180 \mathrm{mg} / \mathrm{l}$ is "hard"; and that having a hardness greater than $180 \mathrm{mg} / \mathrm{l}$ is "very hard." The median hardness of water from the older alluvium in Hualapai Valley is $168 \mathrm{mg} / \mathrm{l}$; the hardness of water ranges from 14 $\mathrm{mg} / \mathrm{l}$ north of Red Lake to $290 \mathrm{mg} / \mathrm{l}$ in the Hackberry well field. The evaporite deposits at Red Lake are a natural water softener. The median hardness of water from the older alluvium in Sacramento Valley and the younger volcanic rocks at Kingman is 203 $\mathrm{mg} / \mathrm{l}$; hardness ranges from 128 to $270 \mathrm{mg} / \mathrm{l}$.

The U.S. Public Health Service (1962) has recommended that the sum of iron and manganese in drinking water not exceed 0.3 $\mathrm{mg} / \mathrm{l}$. More than $0.3 \mathrm{mg} / \mathrm{l}$ iron in water will stain laundry and utensils and will give an unpleasant taste to the water. The median iron concentration in the water from the older alluvium in Hualapai Valley is $0.01 \mathrm{mg} / \mathrm{l}$; values range from 0 to $0.9 \mathrm{mg} / \mathrm{l}$. In both the older alluvium in Sacramento Valley and the younger volcanic rocks at Kingman, the iron concentration in the water ranges from 0 to $0.02 \mathrm{mg} / \mathrm{l}$. 
TABLE 4. - Chemical analyses of water

[Results in milligrams per liter, except as indicated. Remarks: ASHL, analysis by Arizona Station; USGS, analysis by U.S. Geological Survey ;

\begin{tabular}{|c|c|c|c|c|c|c|c|c|}
\hline $\begin{array}{c}\text { Date } \\
\text { of } \\
\text { collection }\end{array}$ & $\begin{array}{c}\text { Depth } \\
\text { (ft) }\end{array}$ & $\begin{array}{r}\text { Silica } \\
\left(\mathrm{SiO}_{2}\right)\end{array}$ & $\begin{array}{l}\text { Iron } \\
\text { (Fe), } \\
\text { in solu- } \\
\text { tion at } \\
\text { time of } \\
\text { analysis }\end{array}$ & $\underset{(\mathrm{Ca})}{\text { Calcium }}$ & $\begin{array}{l}\text { Magne- } \\
\text { sium } \\
(\mathrm{Mg})\end{array}$ & $\begin{array}{l}\text { Sodium } \\
\text { (Na) } \\
\text { and } \\
\text { Potas- } \\
\text { sium } \\
(\mathrm{K})\end{array}$ & $\begin{array}{c}\text { Bicar- } \\
\text { bonate } \\
\left(\mathrm{HCO}_{3}\right)\end{array}$ & $\begin{array}{l}\text { Car- } \\
\text { bonate } \\
\left(\mathrm{CO}_{3}\right)\end{array}$ \\
\hline & & & & & & & \multicolumn{2}{|c|}{ Hualapa } \\
\hline$(\mathrm{B}-20-15) 5 \mathrm{bb} \ldots \ldots \ldots .6-65$ & 785 & $\cdots$ & 0.02 & 68 & 47 & 53 & 336 & 0 \\
\hline 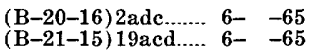 & 152 & $\begin{array}{l}-. . \\
\cdots .\end{array}$ & $\begin{array}{r}.01 \\
4.4\end{array}$ & $\begin{array}{l}79 \\
93\end{array}$ & $\begin{array}{l}28 \\
94\end{array}$ & 102 & $\begin{array}{l}321 \\
298\end{array}$ & $\begin{array}{l}0 \\
0\end{array}$ \\
\hline 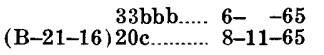 & $\begin{array}{l}700 \\
485\end{array}$ & $\begin{array}{l}-. . \\
\cdots .\end{array}$ & $\stackrel{.01}{1.8}$ & $\begin{array}{r}254 \\
21\end{array}$ & $\begin{array}{l}99 \\
20\end{array}$ & $\begin{array}{l}94 \\
18\end{array}$ & $\begin{array}{l}230 \\
120\end{array}$ & $\begin{array}{l}0 \\
0\end{array}$ \\
\hline (B-22-15) 33dad.... 6-10-65 & 1,220 & 31 & $\ldots$. & 15 & 5 & 83 & 176 & 0 \\
\hline (B-22-16) 26bac..... 2-10-67 & 1,230 & 26 & 0 & 16 & 14 & 32 & 164 & 0 \\
\hline (B-23-13) 19cbb..... 11-10-64 & 150 & $\cdots$ & .9 & 30 & 32 & 42 & 172 & 4 \\
\hline $\begin{array}{r}\text { 19dda....11-10-64 } \\
20 \mathrm{ccd} . . .11-10-64 \\
29 \mathrm{dbc2} . .11-10-64 \\
(\mathrm{~B}-23-15) \text { 8ddd..... } \\
\text { (B-24-16) 1ddd....... } 2-15-65 \\
\end{array}$ & $\begin{array}{r}1,030 \\
355 \\
593 \\
929 \\
\ldots \ldots . .\end{array}$ & $\begin{array}{l}\cdots . . \\
\cdots . . \\
\cdots . . \\
30\end{array}$ & $\begin{array}{l}0 \\
0 \\
.2 \\
.2 \\
.01\end{array}$ & $\begin{array}{l}40 \\
50 \\
69 \\
48 \\
30\end{array}$ & $\begin{array}{r}17 \\
33 \\
28 \\
9 \\
24\end{array}$ & $\begin{array}{l}47 \\
45 \\
42 \\
53 \\
49\end{array}$ & $\begin{array}{l}174 \\
228 \\
240 \\
132 \\
164\end{array}$ & $\begin{array}{r}10 \\
8 \\
12 \\
0 \\
0\end{array}$ \\
\hline 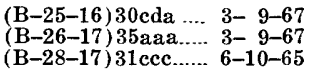 & $\begin{array}{l}600 \\
800 \\
800\end{array}$ & $\begin{array}{l}28 \\
16 \\
6.3\end{array}$ & $0^{.03}$ & $\begin{array}{l}35 \\
25 \\
3.6\end{array}$ & $\begin{array}{c}29 \\
3.0 \\
1.2\end{array}$ & $\begin{array}{r}58 \\
234 \\
460\end{array}$ & $\begin{array}{r}240 \\
72 \\
120\end{array}$ & $\begin{array}{r}0 \\
0 \\
41\end{array}$ \\
\hline
\end{tabular}

\begin{tabular}{|c|c|c|c|c|c|c|c|c|}
\hline Red Lake & ......... & $\ldots$. & $\ldots$ & 7.2 & 5.8 & 289 & 509 & 56 \\
\hline & & & & & & & \multicolumn{2}{|c|}{ Sacramento } \\
\hline$(\mathrm{B}-17-16) 4 \mathrm{dd}$ & ......... & .... & 0.1 & 74 & 30 & 60 & 223 & 9 \\
\hline$(\mathrm{B}-17-17) 31 \mathrm{bcb} \ldots \ldots$ 6-10-65 & 460 & 37 & $\ldots$ & 42 & 22 & 42 & 150 & 0 \\
\hline (B-17-18) 12bca.... 4-27-65 & 1,004 & 37 & ... & 26 & 18 & 46 & 178 & 0 \\
\hline (B-17-18) 12bcb.... 6-17-61 & 787 & $\ldots$. & $\ldots$. & 26 & 23 & 39 & 183 & 0 \\
\hline (B-19-19) 17 baa..... 6- 6-66 & 304 & 68 & .14 & .8 & .2 & 89 & 96 & 53 \\
\hline (B-20-18) 4 bba....... $3-7-67$ & 1,350 & 47 & 0 & 34 & 14 & 51 & 154 & 0 \\
\hline$(\mathrm{B}-21-17) 3 \mathrm{dc} 3 \ldots \ldots . .11-10-64$ & 186 & $\ldots$. & 0 & 45 & 26 & 11 & 204 & 0 \\
\hline $\begin{array}{r}24 \mathrm{cbc} . . . .11-10-64 \\
24 \mathrm{cda} \ldots . . . \\
24 \mathrm{cdb} \ldots . .11-10-64 \\
24 \mathrm{cdd} 2 \ldots 11-10-64 \\
\text { (B-21-18) } 9 \mathrm{bbb} \ldots . . .5-\quad-66\end{array}$ & $\begin{array}{r}178 \\
232 \\
1,518\end{array}$ & $\begin{array}{l}\cdots . . \\
\cdots . . \\
\cdots . . \\
\cdots . .\end{array}$ & $\begin{array}{ll}0 \\
0 \\
0 \\
0 \\
\end{array}$ & $\begin{array}{l}58 \\
66 \\
62 \\
45 \\
54\end{array}$ & $\begin{array}{l}30 \\
25 \\
25 \\
24 \\
22\end{array}$ & $\begin{array}{l}26 \\
25 \\
27 \\
26 \\
82\end{array}$ & $\begin{array}{l}208 \\
200 \\
124 \\
155\end{array}$ & $\begin{array}{r}2 \\
12 \\
12 \\
0 \\
0\end{array}$ \\
\hline $\begin{array}{rr}20 \text { caa..... } & 3-7-67 \\
30 \mathrm{abb} . . . & 3-7-67 \\
32 \mathrm{bbc} . . . & 3-7-67 \\
32 \text { dec..... } & 3-7-67 \\
\text { (B-22-17) } 31 \text { abb2... } & 7-3-63\end{array}$ & $\begin{array}{r}1,285 \\
1,385 \\
1,355 \\
1,255 \\
70\end{array}$ & $\begin{array}{l}36 \\
61 \\
55 \\
43\end{array}$ & $\begin{array}{l}0 \\
.02 \\
0 \\
0 \\
.4\end{array}$ & $\begin{array}{l}57 \\
33 \\
32 \\
36 \\
82\end{array}$ & $\begin{array}{l}24 \\
11 \\
13 \\
14 \\
33\end{array}$ & $\begin{array}{r}55 \\
40 \\
46 \\
50 \\
150\end{array}$ & $\begin{array}{l}150 \\
170 \\
162 \\
148 \\
308\end{array}$ & $\begin{array}{l}0 \\
0 \\
0 \\
0 \\
\ldots . .\end{array}$ \\
\hline$(\mathrm{B}-22-18) 12 \mathrm{caa} \ldots . .7-8-64$ & 120 & $\ldots$. & $\ldots$. & 122 & 47 & 116 & 390 & 0 \\
\hline (B-23-18) 3adb....... & 145 & $\cdots$ & $\ldots$ & 200 & 84 & 100 & $\ldots . .$. & .... \\
\hline $3 b c$ & 210 & $\cdots$. & .... & 260 & 101 & 127 & 304 & 0 \\
\hline $3 \mathrm{cbb} . . . \ldots$. & 104 & .... & $\cdots$ & 200 & 34 & 225 & $\ldots \ldots$. & $\ldots$. \\
\hline $9 \ldots \ldots \ldots \ldots+10-11-65$ & 104 & .... & 2.0 & 272 & 106 & 195 & 232 & $\mathbf{0}$ \\
\hline
\end{tabular}


in Hualapai and Sacramento Valleys

State Health Laboratory; UA, analysis by University of Arizona Agricultural Experiment stratigraphic names indicate water-bearing strata]

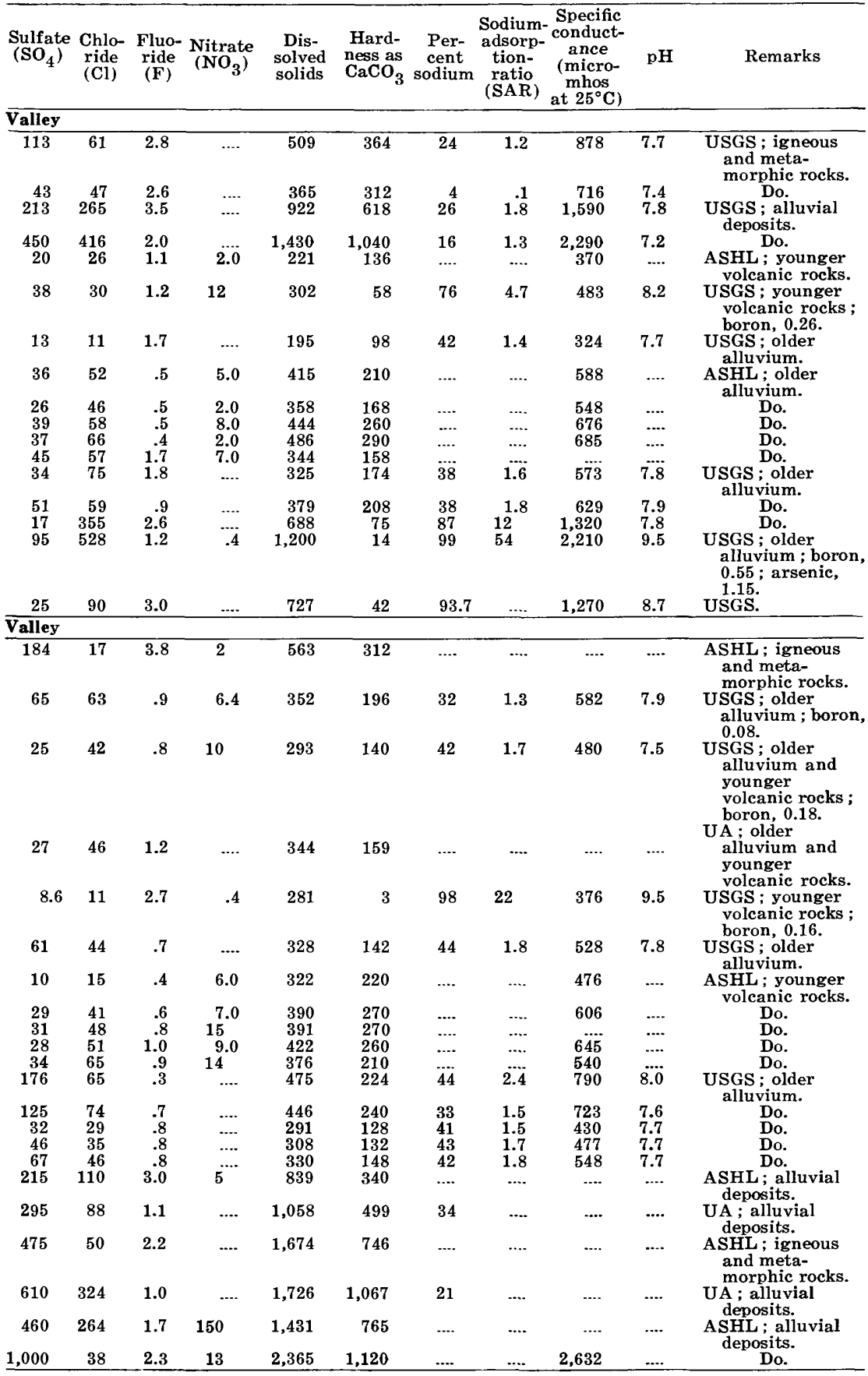


Optimum fluoride concentrations in water help strengthen children's teeth; however, concentrations greater than $1.6 \mathrm{mg} / \mathrm{l}$ - based on the annual average daily maximum air temperature of $77^{\circ} \mathrm{F}$ at Kingman - can be cause for rejection of the supply. The median fluoride content in the water samples from the older alluvium in Hualapai Valley is $1.0 \mathrm{mg} / \mathrm{l}$, and concentrations range from $0.4 \mathrm{mg} / \mathrm{l}$ in water from the Hackberry well field to $2.6 \mathrm{mg} / \mathrm{l}$ in water from the area near Red Lake. The median fluoride concentration in the water samples from the older alluvium in Sacramento Valley and the younger volcanic rocks at Kingman is 0.8 $\mathrm{mg} / \mathrm{l}$, and values range from 0.3 to $1.2 \mathrm{mg} / \mathrm{l}$.

Sodium and magnesium sulfate in excessive concentrations in drinking water have a cathartic effect on people and livestock. Water having a concentration of less than $250 \mathrm{mg} / \mathrm{l}$ sulfate is considered to be safe for human consumption. The median sulfate concentration in the water in the older alluvium in Hualapai Valley is $36 \mathrm{mg} / \mathrm{l}$; concentrations range from 13 to $95 \mathrm{mg} / \mathrm{l}$. In the older alluvium in Sacramento Valley and the younger volcanic rocks at Kingman, the median sulfate concentration in the water is $33 \mathrm{mg} / \mathrm{l}$, and the concentrations range from 10 to $176 \mathrm{mg} / \mathrm{l}$.

Drinking water should contain less than $250 \mathrm{mg} / 1$ chloride. The median chloride concentration in the water in the older alluvium in Hualapai Valley is $58 \mathrm{mg} / \mathrm{l}$, and concentrations range from $11 \mathrm{mg} / \mathrm{l}$ in water from southern Hualapai Valley near Kingman to $528 \mathrm{mg} / \mathrm{l}$ in water from the area north of Red Lake. The high concentration of chloride in ground water north of Red Lake is caused by the solution of sodium chloride in the evaporite deposits in the area. The median chloride concentration in water in the older alluvium in Sacramento Valley and the younger volcanic rocks at Kingman is $46 \mathrm{mg} / \mathrm{l}$, and values range from 15 to $74 \mathrm{mg} / \mathrm{l}$.

A sample of the water from Red Lake was collected for chemical analysis about 3 weeks after the flow of December 10, 1965 (table 4). The sample contained a small amount of suspended red clay, and the $\mathrm{pH}$ value was 9.1 prior to the removal of the suspended material and was 8.7 after removal. The water sample was of the sodium bicarbonate type.

\section{CONCLUSIONS}

Ground-water supplies in Hualapai and Sacramento Valleys are largely undeveloped. Wells drilled in the saturated older alluvium, the main aquifer in the valleys, yield from 25 to 1,500 gpm, depending on well construction and local aquifer conditions. The water is of satisfactory chemical quality for most uses; how- 
ever, wells drilled below a depth of 1,400 feet in the Red Lake area probably will penetrate the evaporite deposits, and the water may be saline. Wells drilled in Sacramento Valley have not penetrated evaporite deposits, although the deposits may exist at depths below 1,500 feet. Water in the highly mineralized areas in and near the mountains is unfit for human consumption.

Depths to water in the main part of Hualapai Valley range from 260 feet below land surface at Red Lake to about 900 feet at the south end of the valley; in Sacramento Valley depths to water range from less than 300 feet below land surface south of Yucca to more than 1,000 feet at the north end of the valley. The depth to water in the younger volcanic rocks at Kingman ranges from 100 to 125 feet below land surface, and the municipal wells yield about $100 \mathrm{gpm}$. As much as 1,400 feet of water-bearing volcanic rocks underlies Kingman, and only the upper 230 feet has been penetrated by wells. It is possible that larger yields could be obtained from wells drilled deeper into these rocks, but, because of the small amount of ground water in storage, large withdrawals of water for long periods of time probably would drain the aquifer.

Wells drilled in the relatively thin veneer of alluvium near the mountainous areas generally yield from 10 to $50 \mathrm{gpm}$. Wells drilled in volcanic rocks and in the fractured or weathered igneous and metamorphic rocks in the mountain areas generally yield from 1 to $5 \mathrm{gpm}$, although well yields of as much as $30 \mathrm{gpm}$ have been reported in these areas.

\section{REFERENCES CITED}

Anderson, T. W., 1968, Electrical-analog analysis of ground-water depletion in central Arizona: U.S. Geol. Survey Water-Supply Paper 1860, 21 p.

Bowen, E. R., and Turner, S. F., 1943, Water supply, [U.S.] Army Air Force Flexible Gunnery School, Kingman, Arizona: U.S. Geol. Survey, open-file report, $7 \mathrm{p}$.

Collins, W. D., Lamar, W. L., and Lohr, E. W., 1934, The industrial utility of public water supplies in the United States, 1932: U.S. Geol. Survey Water-Supply Paper 658, 135 p.

Cooley, M. E., and others, 1967, Arizona highway geologic map: Arizona Geol. Soc. Map.

Dings, M. G., 1951, The Wallapai mining district, Cerbat Mountains, Mohave County, Arizona: U.S. Geol. Survey Bull. 978-E, p. 123-163 [1952].

Fenneman, N. M., 1931, Physiography of western United States: New York, McGraw-Hill Book Co., 534 p.

Ferris, J. G., 1955, Ground-water hydraulics: U.S. Geol. Survey open-file report, $105 \mathrm{p}$.

Gilbert, G. K., 1874, On the age of the Tonto sandstones [abs.] : Washington Philos. Soc. Bull. 1, p. 109. 
Gillespie, J. B., Bentley, C. B., and Kam, William, 1966, Basic hydrologic data of the Hualapai, Sacramento, and Big Sandy Valleys, Mohave County, Arizona: Arizona State Land Dept. Water-Resources Rept. 26, 39 p.

Green, C. R., and Sellers, W. D., eds., 1964, Arizona climate: Tucson, Arizona Univ. Press, 503 p.

Hely, A. G., and Peck, E. L., 1964, Precipitation, runoff, and water loss in the lower Colorado River-Salton Sea area: U.S. Geol. Survey Prof. Paper 486-B, 16 p.

Jacob, C. E., 1950, Flow of ground water, in Rouse, Hunter, ed., Engineering hydraulics: New York, John Wiley \& Sons, p. 321-386.

Lee, W. T., 1908, Geologic reconnaissance of a part of western Arizona, with notes on The igneous rocks of western Arizona, by Albert Johannsen: U.S. Geol. Survey Bull. 352, 96 p.

Longwell, C. R., 1928, Geology of the Muddy Mountains, Nevada, with a section through the Virgin Range to the Grand Wash Cliffs, Arizona: U.S. Geol. Survey Bull. 798, 152 p.

Moore, D. O., 1968, Estimating mean runoff in ungaged semiarid areas: Internat. Assoc. Sci. Hydrology Bull., v. 8, no. 1, p. 29-39.

Murphy, E. C., and others, 1905, Destructive floods in the United States in 1904: U.S. Geol. Survey Water-Supply Paper 147, 206 p.

Noble, L. F., 1914, The Shinumo quadrangle, Grand Canyon district, Arizona: U.S. Geol. Survey Bull. 549, 100 p.

Pakiser, L. C., Jr., Press, Frank, and Kane, M. F., 1960, Geophysical investigation of Mono Basin, California: Geol. Soc. America Bull., v. 71, no. 4, p. $415-447$.

Piper, A. M., and Poland, J. F., 1943, Character and structure of volcanic rocks near Kingman, Arizona, with respect to water-yielding capacity: U.S. Geol. Survey open-file report, 14 p.

Ransome, F. L., 1923, Geology of the Oatman gold district, Arizona - A preliminary report: U.S. Geol. Survey Bull. 743, 58 p.

Schrader, F. C., 1909, Mineral deposits of the Cerbat Range, Black Mountains, and Grand Wash Cliffs, Mohave County, Arizona: U.S. Geol. Survey Bull. 397, 226 p.

Smith, Winchell, and Heckler, W. L., 1955, Compilation of flood data in Arizona, 1862-1953: U.S. Geol. Survey open-file report, 113 p.

Turner, S. F., 1943, Letter regarding a further investigation to determine the possibilities of an additional water supply for the [U.S.] Army Air Force Flexible Gunnery School near Kingman, Arizona: U.S. Geol. Survey open-file report, 5 p.

Turner, S. F., and Poland, J. F., 1943, Letter regarding an investigation to determine the possibilities of an additional water supply for the [U.S.] Army Air Force Flexible Gunnery School near Kingman, Arizona: U.S. Geol. Survey open-file report, $11 \mathrm{p}$.

Twenter, F. R., 1962, Geology and promising areas for ground-water development in the Hualapai Indian Reservation, Arizona: U.S. Geol. Survey Water-Supply Paper 1576-A, 38 p.

U.S. Public Health Service, 1962, Drinking water standards, 1962: U.S. Public Health Service Pub. 956, 61 p.

University of Arizona, 1965a, Normal annual precipitation - normal MaySeptember precipitation - 1931-1960, State of Arizona: Arizona Univ. Map. 
$1965 \mathrm{~b}$, Normal annual precipitation - normal October-April precipitation - 1931-1960, State of Arizona: Arizona Univ. Map.

Wilson, E. D., 1962, A résumé of the geology of Arizona: Arizona Bur. Mines Bull. $171,140 \mathrm{p}$.

Wilson, E. D., and Moore, R. T., 1959, Geologic map of Mohave County, Arizona: Arizona Bur. Mines Map. 